\title{
The effect of immigrant peers in vocational schools"
}

\author{
Tommaso Frattini, University of Milan, CEPR, CReAM, IZA and LdA \\ Elena Meschi, University of Venice Ca'Foscari
}

\begin{abstract}
This paper provides new evidence on how the presence of immigrant peers in the classroom affects native student achievement. The analysis is based on longitudinal administrative data on two cohorts of vocational training students in Italy's largest region. Vocational training institutions provide the ideal setting for studying these effects because they attract not only disproportionately high shares of immigrants but also the lowest ability native students. We adopt a value added model, and exploit within-school variation both within and across cohorts for identification. Our results show small negative average effects on maths test scores that are larger for low ability native students, strongly non-linear and only observable in classes with a high (top 20\%) immigrant concentration. These outcomes are driven by classes with a high average linguistic distance between immigrants and natives, with no apparent additional role played by ethnic diversity.
\end{abstract}

Keywords: Immigration, education, peer effects, linguistic distance, ethnic diversity.

JEL codes: I20, J15

\footnotetext{
* We would like to thank the editor, three referees as well as Dalit Contini, Christian Dustmann, Fabian Lange, Giovanni Peri, Jan Van Ours, and participants in several workshops, conferences and seminars at the University of Venice Ca' Foscari, University of Ancona, ISER, EUI, University of Barcelona, University of Groningen, AIEL, IWAEE, University of Turin, EU-JRC (Ispra) and the $7^{\text {th }}$ Annual Conference on Immigration in OECD countries for their useful comments on earlier versions of this paper. Special thanks go to EUPOLIS for giving us access to their microdata and to Alicia Adsera and Mariola Pytlikova for kindly providing us data on linguistic distance. The usual disclaimers apply.
} 


\section{Introduction}

In recent years, most OECD countries, even those with historically low immigration, have witnessed a substantial increase in migrant inflow. In 2015, for instance, $11.1 \%$ (43.9 million) of EU-15 country residents were foreign born, according to the EU Labour Force Survey, up from 6.3\% in 1990 and 8.2\% in 2000 (UN Population Division). The surge has been especially high in Southern European countries like Spain and Italy, where immigrant shares of the population have increased by 7 and 5.5 percentage points, respectively, to $12 \%$ and $9 \%$. Yet although research on the labour market (e.g. Borjas, 2003; Card, 2001 and 2005; Dustmann et al., 2013; Ottaviano and Peri, 2012) and fiscal effects (Auerbach and Oreopoulos, 1999; Storesletten, 2003; Dustmann and Frattini, 2014; Preston, 2014) of immigration in receiving countries is extensive, less is known about the impact of such inflows on the education system. This latter aspect is important because of the rising shares of immigrant students in most advanced countries, accounting for $12 \%$ of 15 -year-old students across OECD countries in 2012 and increasing between 4 and 6 percentage points in Ireland, Italy and Spain from 2003 to 2012 (OECD, 2015). At the same time, in many countries, especially in Europe, the children of immigrants exhibit significant gaps in school performance relative to native children (Schnepf, 2007; Dustmann et al. 2012), an educational disadvantage that has sparked fears that these latter's learning achievements may be threatened by the presence of immigrant students in the classroom. These concerns often motivate native students to move out of schools with a high immigrant concentrations (the socalled 'native flight'), leading to the immigrant school segregation documented in both U.S. and European contexts (e.g. Betts and Fairlie, 2003; Cascio and Lewis, 2012; Farrè et al., 2015). The concern that such large concentrations may harm native educational attainment is theoretically rationalisable within Lazear's (2001) education production function model, in which classroom teaching is a public good for which congestion effects matter. Immigrant students may be more likely to require special attention and potentially create negative externalities for two main reasons. First, they often come from families with a poor socioeconomic background and they thus tend to have lower performance compared to natives. As a result, they are more likely to be concentrated at the bottom of the academic ability distribution - where peer effects are strongest (Lavy, Silva, and Weinhardt, 2012). Moreover, immigrants tend to have lower command of the host country's language and may require a disproportionate amount of teacher attention, thereby diverting teaching resources away from 
other students. The literacy deficiency may also prompt teachers to slow the pace of instruction to accommodate migrant student comprehension (Hunt, 2016).

Whether these concerns are justified, however, is empirically less clear, and the issue remains a thorny one for a recent immigration country like Italy. In this paper, therefore, we throw more light on whether and how a concentration of immigrants in the classroom affects native student outcomes by taking advantage of a unique administrative dataset on the universe of students in vocational training institutions in Italy's largest region, Lombardy. Vocational schools have so far been neglected in the immigrant peer effects literature. However, our focus on these institutions is motivated by two types considerations. First, vocational schools are an ideal setting for studying immigrant peer effects because they attract not only high shares of immigrants (Carlana, La Ferrara and Pinotti, 2017) but also the lowest achieving natives, who are typically most affected by peer effects (Angrist and Lang, 2002). Second, by providing students not only with general knowledge and skills, but also with practice-oriented training to prepare them for particular occupations, they can be one of the most important policy tools available for combating youth unemployment (Eichhorst, 2015), which is a particularly pervasive issue especially in Southern European countries. Our results show that the presence of immigrant students in the classroom has no effect on native students' literacy achievements but does slightly hold back their maths scores. These effects, although quantitatively small on average, are larger for low ability native students. They are also strongly non-linear and observable only in classes with a high (top 20\%) immigrant concentration. We further investigate the mechanisms through which these effects could operate, and demonstrate that ethnic diversity plays no role whereas the results are driven by classrooms with a high average linguistic distance between immigrants and natives.

Our paper is related to the large body of literature on peer effects in education (see Sacerdote, 2011 for a review) and particularly to the more recent work on immigrant peer effects. This literature, however, is not only rather sparse but offers mixed results, with studies differing in identification strategy adopted, type of data used, age groups considered and geographic focus (Jensen, 2015, and Brunello and De Paola, 2017, provide useful reviews). For example, two early studies by Brunello and Rocco (2011) and Jensen and Rasmussen (2011), who use PISA data to exploit cross-country and cross-regional geographic variation, respectively, find small but significant negative effects of immigrants on native performance in secondary school, an effect that is limited to maths in Jensen and Rasmussen (2011). Others who adopt a tighter identification strategy reliant on within-school variation in the immigrant student share, 
however, tend to find zero or weakly negative peer effects. For instance, Ohinata and van Ours (2013), using PIRLS and TIMMS data for the Netherlands, and Geay, McNally and Telhaj (2013), using administrative data from the British National Pupil Database, find no evidence of any spill-over effects from the presence of immigrant children (non-English speakers in Geay et al.) on the test scores of native students in primary schools. Gould, Lavy and Paserman (2009), in contrast, focusing on other outcomes and exploiting the 1990 mass migration of Russian immigrants to Israel, find that immigrant concentration in primary school does adversely affect the dropout rate of native Israelis, as well as their chances of passing the high school exam necessary to attend college. ${ }^{1}$

Three more recent papers focus specifically on the Italian experience by analysing administrative data on the standardized INVALSI test in primary and lower secondary schools. Two of these, relying on within-school variation in immigrant concentration, find that the proportion of immigrant students has a weak negative effect on child learning outcomes that is either slightly larger for children from low socio-economic background (Contini, 2013) or highly non-linear (Tonello, 2016). In contrast, Ballatore, Fort and Ichino (2018), by exploiting class formation rules to identify the causal impact on native test scores of increasing the number of immigrants in a classroom while keeping class size and student quality constant, find sizable negative effects on native performance in both literacy and maths at ages 7 and 10. To explain the magnitude of their findings, they argue that conventional estimates of immigrant peer effects are usually smaller because they are confounded by endogenous class size adjustments implemented by principals confronted with immigrant and native inflows.

Our paper contributes to this literature along several dimensions. First, we focus on the vocational schools that previous studies overlook even though these institutions attract both a disproportionate share of immigrant students and the most disadvantaged segment of the native student population. If immigrant peer effects are non-linear, with their strength increasing at higher concentrations (Tonello, 2016) and lower-ability students are more vulnerable to the negative externalities that may arise as a consequence of class composition (Hanushek et al. 2003 and Lavy, Paserman and Schlosser, 2012), then it is very likely that the negative effect of immigrant peers are largest in vocational schools. Second, by employing a

\footnotetext{
${ }^{1}$ Anelli et al. (2017) is the only paper that has analysed immigrant peer effects among university students, showing that the presence of foreign peers reduces the likelihood that U.S.-born students graduate with STEM majors.
} 
large administrative dataset encompassing the entire population of vocational track students, we reduce the peer variable measurement error inherent in surveys that do not sample all students in a class or school (Micklewright et al., 2013) while also overcoming the underrepresentation of immigrant share typical in survey data (Aydemir and Borjas, 2011). Third, the fact that our dataset includes the scores for students tested at the beginning of the first year allows us to perform several balancing tests to validate our identification strategy and to implement value added models that help reduce the omitted variable bias in the modelling of the education production function (Todd and Wolpin, 2003). Lastly, we allow for nonlinearity in the estimation of peer effects and we investigate the underlying channels through which the effect may be operating, testing particularly for the involvement of ethnic diversity or linguistic distance. In fact, to the best of our knowledge, ours is the first study to examine the role of diversity in immigrant peer groups while also studying compositional effects.

The rest of the paper is structured as follows: section 2 describes the data and reports relevant descriptive statistics. Section 3 explains our empirical approach and identification strategy, after which section 4 outlines several possible threats to identification and the various tests used to validate our identifying assumptions. Section 5 presents the results, and section 6 concludes the paper with a discussion of possible policy implications.

\section{Data and descriptive statistics}

Our analysis is based on administrative data for all students earning a three-year vocational qualification certificate in 2012 or 2013 in any of Lombardy's vocational secondary institutions, which all fall under the governance of the regional authority. Being the largest Italian region, Lombardy, whose inhabitants totalled 9.8 million in 2013, accounts for $16 \%$ and $15 \%$ of the Italian and total school student populations, respectively, but for a disproportionate $24 \%$ of the immigrant school population. It also has the highest immigrant share of school population in the nation (14\% compared with a national average of $8 \%)^{2}$

In Italy, although education is compulsory from age 6 to age 16, after completing lower secondary school at age 14 , students can choose between three different tracks: academic,

\footnotetext{
${ }^{2}$ Source: ISTAT Geodemo, www.demo.istat.it and I.Stat based on "Rilevazione sulle scuole secondarie di secondo grado" $\quad$ run $\quad$ by $\quad$ (year (http://dati.istat.it/Index.aspx?DataSetCode=DCIS_SCUOLESECOND2\# ).
} 
technical and vocational. ${ }^{3}$ The vocational track involves two types of institutions: vocational schools (istituti professionali), whose five-year programs give direct access to university; and vocational training institutions (formazione professionale regionale), organized at a regional level, whose programs last three or four years, with a possible fifth year for students seeking access to higher education. These vocational training schools, although overseen by regional authorities, are part of the national education system and organized along two basic pathways: three-year courses, leading to the award of a vocational qualification certificate (attestato di qualifica di operatore professionale $)^{4}$ and four-year courses, leading to a professional technician diploma (diploma professionale di tecnico). ${ }^{5}$ These schools, although aimed primarily at the acquisition of basic, transversal and technical-occupational skills, must balance general and vocational subjects at about 50\% each of total school time (about 1,000 hours a year, as in all upper secondary institutions on any track). Students attend classes for about 5-6 hours a day, 5 or 6 days a week, starting in September and ending in June, following the standard Italian school calendar (see Cedefop 2014). Schools on the vocational track are characterized by a disproportionate share of immigrant students, both in Italy as a whole and in Lombardy, where almost $20 \%$ of vocational students are foreign born, compared with $10 \%$ on the technical track and less than $5 \%$ on the academic track (Figure 2.1).

[Figure 2.1]

As illustrated by the breakdown in Figure 2.2 of student shares attaining different PISA achievement levels, the performance of students on the vocational track is significantly lower than that of students on the academic or technical tracks. Despite the average good performance of students across the region (14\% in the lowest class, versus $25 \%$ in Italy and $26 \%$ across OECD countries), a remarkable $50 \%$ of students in Lombardy's vocational training institutions are among the lowest educational achievers.

[Figure 2.2]

\footnotetext{
${ }^{3}$ See Braga, Checchi and Meschi (2013) for more details on the institutional features of school systems from an international perspective.

${ }^{4}$ This certificate corresponds to Level 3 in the European Qualifications Framework (EQF) (see http://ec.europa.eu/ploteus/search/site?f[0]=im_field_entity type\%3A97\#)

5 The qualifications awarded under the regional system are recognized at both the national level and within Europe, with a national register of qualifications awarded in the VET system created in 2011. Students holding a professional technician diploma can continue into the Higher Technical Education and Training System (IFTSITS) or higher education on completion of an additional year and after passing a state exam (see ISFOL, 2008, for more details on vocational education in Italy).
} 
In particular, our dataset contains information on two student cohorts that entered the regional vocational training system in Lombardy in 2009 and 2010, respectively, and earned their vocational qualification certificates in 2012 and 2013 after a three-year course. All students take standardized, externally marked (graded) tests in Italian literacy and maths at the beginning of the first year and again at the end of the third year as part of the final exam. In addition to test scores, our dataset also records student gender, age and country of birth. We use this latter to define immigrant status, designating all foreign-born students as immigrants. This ability to identify birth country (albeit not second-generation immigrants) is a key advantage of our data in that it allows us to study each class's immigrant group composition to assess whether diversity plays a role. Another important advantage is our coverage of the universe of students attending vocational courses in Lombardy, which enables us to match students with their classmates and thereby reduce the measurement error in peer variable construction that often characterizes survey-based studies (see Ammermueller and Pischke, 2009; Micklewright et al., 2013). In addition, although the dataset provides little information on individual characteristics and family background per se, we are able to use beginning of the first year test scores to capture all the unobserved individual, school and family characteristics that affected school performance before the student's entry into vocational training.

Our sample comprises 14,434 students $(6,233$ in the first and 8,201 in the second cohort) who completed the vocational training course and earned a qualification at the end of the third year. As Table 2.1 shows, consistent with the MIUR aggregate data in Figure 2.1, about 18\% of students are foreign born, ${ }^{6}$ which confirms the high share of immigrants in vocational institutions. As expected, most students are between 17 and 18 years old, with deviations from this age group probably the result of grade repetition. The students overall, $44 \%$ of whom are female, are allocated between 1244 classes $^{7}$, with an average 3.5 classes per school, a mean class size of 17.9 , and a mean immigrant share per class of $19 \% .^{8}$

\footnotetext{
${ }^{6}$ Albania, Morocco, Romania, India, Ecuador, Pakistan, Senegal, Peru, Moldova and Ukraine are the leading origin countries, accounting for almost $70 \%$ of the immigrants in our sample.

${ }^{7}$ Students are assigned to a given class at the beginning of the 3-year course and then stay in the same class throughout the whole program, taking all courses together with their initial classmates (see http://www.indire.it/lucabas/lkmw_img/eurydice/quaderno_eurydice 30_per_web.pdf).

${ }^{8}$ The initial sample includes some students allocated to very small classes. Even though the regional vocationl training system is not subject to state regulations on minimum class size, for administrative reasons most institutions set a minimum number of students per class. Therefore, classes with a very small number of students are likely to be the result of measurement error, or to be very idiosyncratic in their characteristics. For this reason, in our analysis, we exclude all classes with less than nine students, which results in dropping 125 (1.9\%)
} 
[Table 2.1]

Table 2.1 (bottom rows) reports the summary statistics for the initial maths and literacy test scores, broken out separately for immigrants and natives and standardized to have a mean of zero and a standard deviation of one in each wave. Clear differences emerge not only for the means but also for the native and immigrant score distributions, especially for literacy; just as the -0.41 value for the $25^{\text {th }}$ percentile of the native literacy distribution is higher than the -0.56 mean value for immigrants, so the 0.13 value for the $75^{\text {th }}$ percentile of the immigrant score distribution is lower than the 0.16 mean for natives. Hence, natives have higher test scores than immigrants in both subjects, but the largest difference is for literacy.

\section{Identification of Peer Effects and Empirical Strategy}

The main challenge in estimating peer effects is that rather than being assigned to schools randomly, students with similar backgrounds tend to choose similar schools. For example, advantaged students with higher ability levels and better access to information typically choose better schools. The peer group is thus likely to be self-selected, especially in the case of immigrants, who, given more limited information access and residential segregation, tend to sort into disadvantaged schools that typically also have a concentration of low-ability natives. Yet if immigrants are not randomly allocated to schools, then the impact of class composition could easily be confounded with school-specific unobservable effects, leading to biased estimates of the peer effects.

To deal with this endogenous student sorting across schools and to identify causal effects, previous studies adopt various empirical strategies. One method is to rely on some form of exogenous variation in student assignment to schools or classrooms. Duflo et al., (2011), for example, exploit the variation in peer composition generated by actual randomization, while Angrist and Lang (2004) leverage the substantial increase in the number of disadvantaged black or other minority students in the schools in Boston's affluent suburbs as a result of the Metropolitan Council for Educational Opportunity's (Metco) desegregation program. Gould et al. (2009) similarly rely on the variation in number of immigrant students induced by the exogenous immigration waves to Israel in the early 1990s, while Ballatore et al. (2018) use the exogenous variation in the number of natives and immigrants generated by the

observations. All our results are robust to the choice of alternative thresholds as well as to the inclusion of all observations. 
compulsory cap of 25 students per class in Italian primary schools. Still other papers overcome the issue of endogenous sorting of students between schools by aggregating the data at city, state or country level (see e.g. Card and Rothstein, 2007; Brunello and Rocco, 2011; Jensen and Rasmussen, 2011; Hunt, 2016). Another common method is to use school fixed effects models to control for the unavoidable self-selection into schools. Research using this latter approach identifies peer effects by exploiting the idiosyncratic within-school variation in peer characteristics across adjacent cohorts (Hoxby, 2000; Lavy and Schlosser, 2011; Lavy, Paserman and Schlosser, 2011; Burke and Sass, 2013; Geay, McNally and Telhaj, 2013) or across classes in the same cohort (Ammermueller and Pischke, 2009; Ohinata and van Ours, 2013).

Our identification strategy relies on the random variation of students across both classes and adjacent cohorts within schools. In particular, we estimate the following model, derived from a reduced form of an education production function:

$$
Y_{i c s t}=\rho Y_{i c s t}^{0}+X_{i c s t}^{\prime} \alpha+C_{c s t}^{\prime} \beta+\gamma I M M S H A R E_{c s t}+\delta_{s}+\vartheta_{t}+\varepsilon_{i c s t}
$$

where $Y_{i c s t}$ is the outcome (standardized final test scores in either maths or literacy) of native student $i$ in classroom $c$, school $s$ in cohort $t ; Y^{0}$ is the student's outcome at the beginning of the first school year; $X_{i c s t}$ and $C_{c s t}$ are student and class characteristics (class size, share of females), respectively; IMMSHARE is the immigrant share in each class measured in the final year; $\delta_{s}$ are school fixed effects; $\vartheta_{t}$ are cohort dummies and $\varepsilon_{i c s t}$ is the error term. Because immigrant share does not vary at the individual level, we adjust the standard errors for clustering at the class level.

If students are randomly allocated across classes and cohorts within schools, then school fixed effects allow us to control for systematic cross-school variation in school or student quality, thereby overcoming the issue of endogenous student selection. In this case, parameter $\gamma$ identifies the causal impact of immigrant share on native performance. Our main identification assumption is that once school-specific unobserved characteristics are controlled for, students are allocated randomly to each class within a school. We will provide several tests of the validity of such an assumption in section 4 . 
When studying peer effects in education, a second, and often neglected, identification issue is how to model the education production function. That is, because student academic achievement at a given point in time is a function of all past and present inputs from family, student and school - for which full data are seldom available - estimating the impact of observed inputs is likely to suffer from an omitted variable bias (see e.g. Todd and Wolpin, 2003, 2007). Our strategy to overcome this lack of data on historical input measures is to adopt a value added specification, which relies on the assumption that previous test scores are sufficient statistics for the effect of all past inputs (Todd and Wolpin, 2007). ${ }^{9}$

\section{Threats to identification}

Keeping in mind our key identifying assumption that once school-specific unobserved characteristics are controlled for, student allocation to each class within a school should be random (see section 3), we now perform several validity tests on our identification strategy. First, we test whether the observed immigrant distribution across classes in each cross-section is compatible with random assignment. Second, we check whether the immigrant concentration in each class is systematically correlated with native (or immigrant) initial ability. Third, we assess whether the immigrant share in a classroom affects the dropout likelihood for natives. Lastly, we check for possible non-random variation of immigrant share across adjacent cohorts, due to native flight, i.e. the possibility that higher immigrant concentration may lead native students to choose different schools in subsequent years. All these tests are conducted using immigrant share at the start of the first school year, before any school changes or dropouts could have taken place ${ }^{10}$.

\subsection{Random assignment test}

Because random allocation implies independence between immigration status and a student's assigned class, we can test the randomness of assignment across classes within schools using the Pearson $X^{2}$ test (cf. Ammermueller and Pischke, 2009) of whether the number of

\footnotetext{
${ }^{9}$ To the best of our knowledge, the only other authors that study immigrant peer effects using a value added approach are Friesen and Krauth (2011) and Geay et al., (2013).

${ }_{10}$ Another potential threat to identification may be non-random sorting of teachers across classrooms (see Ohinata and Van Ours, 2013). Unfortunately, we do not have any information on teachers in our dataset. Therefore, we are not able to address this concern and check whether teacher characteristics are correlated with immigrant shares.
} 
immigrants in a particular class is consistent with independence given the number of students in the school. Formally, we write the test statistic for each school as follows:

$$
P=\sum_{C} \frac{\left(n_{c I M M}-\widehat{n_{C I M M}}\right)^{2}}{\widehat{n_{C I M M}}}+\sum_{C} \frac{\left(n_{c N A T}-\widehat{n_{C N A T}}\right)^{2}}{\widehat{n_{C N A T}}}
$$

where $n_{\text {CIMM (NAT) }}$ is the number of immigrant (native) students in classroom $c=1, \ldots, C_{s}$, and $\widehat{n_{C I M M(N A T)}}$ is the predicted number of immigrant (native) students when immigrant status and classroom are independent; that is, when the total number of immigrant students in the school is allocated to each class $c$ according to the proportion of overall students in that class. This latter implies that the joint probability of a randomly chosen student from a given school having a migrant background and being assigned to class $c$ is equal to the total number of migrants in the school times the proportion of students in class $c$ :

$$
\widehat{n_{c, I M M}}=\frac{N_{c} * N_{s c h}^{I M M}}{N_{s c h}} \quad \widehat{n_{c, N A T}}=\frac{N_{c} * N_{s c h}^{N A T}}{N_{s c h}}
$$

where $N_{s c h}^{I M M}$ is the total number of immigrant students in the school, $N_{c}$ is the total number of students in class $c$ and $N_{s c h}$ is the total number of students in the school. Under the null hypothesis of independence, $P \sim X^{2}$ with $\left(C_{s}-1\right)$ degrees of freedom. We perform these tests for every single school in each cohort and report the distribution of $p$-values in the two cohorts in Table 4.1. In about $90 \%$ of the schools, we cannot reject the random assignment of students across classes at the 5\% significance level (i.e. the $p$-values are above the $5 \%$ level in about $90 \%$ of the schools in both cohorts). ${ }^{11}$

[Table 4.1]

\subsection{Non-random sorting of immigrants and natives between classes within schools in each cohort}

To deal with the concern that school principals might concentrate more immigrants in classes with "better" or "worse" native students, in Panel A of Table 4.2, we report the results of regressing native test scores at entrance (i.e. before any peer effects have taken place) on the

\footnotetext{
${ }^{11}$ All our results are robust to the exclusion of the schools where can reject the null hypothesis of random assignment at the $5 \%$ level.
} 
initial share of immigrants in the classroom and additional control variables (gender, age, class size, share of females, cohort dummies). Columns 1 and 2, which report the results for literacy and maths test scores, respectively, when school fixed effects are excluded, show clear evidence of negative sorting between schools. Once we include school dummies, however (columns 3 and 4), there is no indication of any systematic correlation between the immigrant student share in each class and the initial literacy or maths proficiency of native students. This finding is an additional indication that our identifying assumption is likely to hold. However, even though we have demonstrated that there is no systematic sorting of immigrants on average, there could still be some sorting at the extreme of immigrants' share distribution. To address this potential concern, in Panel B of Table 4.2 we report results from regressions similar to those of Panel A, but where we have replaced the initial share of immigrants in the classroom with a set of dummies for being in different quintiles of the initial immigrant share distribution. Reassuringly, none of the four dummies is statistically significant at any conventional levels, once school fixed effects have been appropriately controlled for.

[Table 4.2]

Nonetheless, the concern remains that the allocation of immigrants across classes may not be random with respect to their own ability (e.g. principals might decide to allocate more immigrants to a class who have relatively good past school performance). Because we have data on immigrants' initial test scores, we test this hypothesis by regressing the immigrants' entrance test scores in maths and literacy on the immigrant share in the class both excluding and including school fixed effects. Table 4.3, which has the same structure of Table 4.2, reports the results. Again, once we control for school fixed effects, no systematic correlation is observable between immigrant share and immigrant ability.

[Table 4.3]

\subsection{Native dropout}

An additional concern on the validity of our identification strategy is whether a higher immigrant share in a class could increase the probability of natives dropping out. For instance, if a higher initial concentration of immigrants led the best native students to drop out of 
school, then we would observe a spurious negative correlation between immigrant share and native test scores because of unfavourable selection. As a result, our estimates of immigration's causal impact on native achievement would be downward biased. This concern is especially relevant for our vocational track context because the drop-out rates in vocational schools are particularly high (about $40 \%$ in our sample). Because our dataset includes information on class composition at the beginning of the first school year, we can directly test for any possible effect of initial immigrant share on the probability of native dropout. To do so, we estimate a linear probability model in which we regress, for each native student, the probability of dropping out on the initial share of immigrants in the class and on the usual set of additional control variables (initial test score, age, gender, class size, share of females in the class, cohort dummies) both with and without school fixed effects. The results, reported in Table 4.4, indicate that, although natives in classes with a higher share of immigrants are generally more likely to drop out of school (column 1), this finding results from the clustering of immigrants in schools characterized by higher dropout rates. Once we use school fixed effect to control for sorting across schools, the correlation not only becomes negative but much smaller in magnitude and not statistically significant at conventional levels (column $2)^{12}$.

[Table 4.4]

Nevertheless, as comforting as these results may seem, the question remains of whether the absence of an average effect on dropout rates originates from opposite effects on high and low ability native students. To investigate this possibility, we run separate regressions for native students with high and low initial ability. We measure ability as the mean of the maths and literacy test scores at entrance, and then define "high" or "low" ability students, respectively, as those with a score above or below the median value. Reassuringly, our estimates indicate the absence of any impact on dropout rates for both groups (columns 3-6).

\footnotetext{
${ }^{12}$ We have also tested the effect of immigrant share on immigrants' dropout probability. Our results (available upon request) suggest that the effect is very small: a 10 percentage point increase in the initial immigrant share approximately a $50 \%$ increase relative to the mean - would lead to a decrease of about $1 / 30$ of a sd in immigrants' dropout probability. Additionally, this result is entirely driven by the $3 \%$ of classes with an initial immigrant share higher than $60 \%$. Reassuringly, dropping these classes from our estimating sample, does not affect our results.
} 


\subsection{Native flight}

Another potential threat to identification is the native flight phenomenon (see Betts and Fairlie, 2003) ${ }^{13}$ by which the best native students could change schools as a result of a high immigrant concentration, meaning that the variation in these schools' quality over time would not be random. In this case, estimates of a negative impact of immigrant concentration on native students may simply reflect selective school enrolment by both immigrant and native children. To test this latter possibility, we run school-level regressions of the change in natives' mean initial ability between the second (2010 entrance) and first cohort (2009 entrance) on the immigrant share of the school population for the first cohort, as well as on the usual set of additional control variables. The results indicate that the variation in the average quality of incoming students over time is unaffected by past immigrant shares in the school. $^{14}$

\section{Results}

\section{1: Baseline results}

The results of our main specification are reported in Table 5.1, which shows the effect of immigrant share on native student scores for literacy (columns 1-3) and maths (columns 4-6). Whereas columns 1 and 4 report the results for the full sample, in columns $2-3$ and 5-6, we divide the sample by initial test scores to test whether or not peer effects are homogenous along the ability distribution, in which high (low) equates to a mean initial maths and literacy score above (below) the median. ${ }^{15}$

\section{[Table 5.1]}

Once we control for non-random sorting of students across schools, the share of immigrants does not significantly affect natives' literacy scores but does have a small negative effect on their maths scores, with a 10 percentage point increase in immigrant share $(66 \%$ of a standard deviation) generating a $5 \%$ of a standard deviation decrease in score. To appreciate the size of the effect, consider that women's maths test scores are $8.3 \%$ of a standard deviation lower than men's. Therefore the share of immigrants should increase by more than 16 percentage

\footnotetext{
${ }^{13}$ Betts and Fairlie (2003) coined the expression 'native flight' to describe the tendency of native-born Americans to leave public schools for private alternatives following an increase in immigration share in their home communities.

${ }^{14}$ The coefficient and standard error are -0.22 and 0.175 , respectively.

${ }^{15}$ These results are robust to using alternative definitions of high and low ability, including above and below the mean or above the $75^{\text {th }}$ percentile and below the $25^{\text {th }}$ percentile.
} 
points to mimic the effect of gender. Although this finding (lack of any adverse effect on literacy test scores and negative effects on maths) may initially seem counterintuitive, it is in line with the educational literature's claim that language is essential for mathematical learning (Ríordáin and O'Donoghue, 2009), which is supported by evidence that students underachieve in mathematics when school language differs from home language. In multilingual settings, maths teachers must deal not only with the language practices that learners bring to school but with the fact that "discontinuities in understanding new words and new meanings can turn into a wide variety of cultural conflicts and disruptions of the learning process" (Gorgoriò and Planas, 2001). Moreover, the stronger impact on maths may result from the fact that although performance on the literacy test depends mainly on language proficiency (which is in turn related to family background and competences acquired in primary and lower secondary schools), attainment in maths is influenced more by the school learning environment and peer effects.

As Table 5.1 also shows, the impact of immigrant concentration is not homogenous along the native ability distribution. In fact, when we run separate regressions by native ability (columns 5 and 6), we find that the average negative effect discussed above is due entirely to the larger impact on low ability native students for whom a 10 percentage point increase in immigrant share leads to a $8.1 \%$ of a standard deviation decrease in test scores. This finding is consistent with evidence from previous peer effects studies that a higher immigrant concentration in the class or school is more likely to adversely affect disadvantaged than advantaged children (e.g. Gould et al., 2009; Angrist and Lang, 2004). The effect on high ability natives, in contrast, is both smaller in magnitude and very imprecisely measured. A test for the equality of the low and high ability coefficients indicates rejection of the null hypothesis of no difference with a $p$-value of 0.06 .

At the same time, the immigrant shares across classes in our sample vary considerably. While the mean value of the share of foreign-born students per class is $19 \%$, moving from the $25^{\text {th }}$ to the $75^{\text {th }}$ percentile of the distribution, signifies a jump from $8 \%$ to almost $30 \%$ (see Table 2.1). Such variation may indicate that constraining this variable's impact to be linear may be too restrictive: its effect may manifest only when the immigrant concentration in a class is above a certain threshold. Hence, in Table 5.2, we test for non-linearities in the effects of immigrant concentration by using as regressors dummy for each quintile of the distribution of immigrant share in each cohort. 
Our results not only confirm the lack of any immigrant peer effects on literacy scores, even for classes with a very high share of immigrant students, but also provide strong evidence of non-linearities in the effect for mathematics. That is, students in classrooms whose immigrant share is in the second, third or fourth quintile of the distribution show no significant test score differences from students in classes with an immigrant share in the first quintile. On the other hand, being in the fifth quintile implies almost a $25 \%$ of a standard deviation reduction in maths scores relative to being in the first quintile. ${ }^{16}$ This finding suggests that negative peer effects arise only when the proportion of immigrants is high (cf. Hardoy and Schøne, 2013; Tonello, 2016). ${ }^{17}$ If we split the estimates by native ability, we again find that the effect of a high immigrant concentration is stronger and larger for low ability natives. Moreover, as the column 5 results indicate, the critical threshold is lower for low ability students, for whom negative effects are observable even in classes in the fourth quintile of the immigrant share distribution.

Overall, then, these estimates suggest that although immigrant peers have a rather small effect on native students' maths scores on average, the effect is larger for low ability native students and driven by classes in which the immigrant concentration is particularly large. This latter implies that as long as the immigrant share in a class is sufficiently low, the presence of nonnative students will not generate negative peer effects on native outcomes. Understanding the channels at work here, however, requires a more in-depth examination of the other dimensions of heterogeneity. ${ }^{18}$

\subsection{The role of diversity and language distance}

Based on our results so far, a high share of immigrants in the class may have a mildly detrimental effect on native academic performance. Hence, in this section, we investigate

\footnotetext{
${ }^{16}$ Moving from the first to the fifth quintile implies about a 40 percentage point increase in immigrant share, from a mean of $0.02 \%$ to $41 \%$.

${ }^{17}$ As an alternative test for non-linearity, we also introduce a linear spline functional form in IMMSHARE, with a threshold set at the median (0.15), which allows the marginal effects to differ below and above the median. We find significant negative marginal effects only for high (i.e. above the median) levels of immigrant share in the class, for which a 10 percentage point increase in IMMSHARE generates a $10.4 \%$ of a standard deviation reduction (results available upon request).

${ }^{18}$ We have also tested whether there is any gender heterogeneity in immigrant peer effects, by interacting immigrant share in the classroom with a female dummy. The results (available upon request) show that the coefficient of the interacted term is small in magnitude and far from being statistically significant at any conventional level.
} 
what drives this effect; in particular, whether the degree of the immigrant group's diversity or the linguistic distance of their own languages from Italian play a role. As regards the first, although several studies examine the role of ethnic diversity on economic and social outcomes, the findings are mixed: whereas ethnic diversity may negatively affect trust and solidarity (Putnam, 2007) and the provision of public goods (Alesina and La Ferrara, 2005), it can have a positive effect on native productivity (Ottaviano and Peri, 2006) as well as on economic prosperity (Alesina et al. 2016). Likewise, in the school setting, although ethnic diversity may worsen student social interaction and make teachers' jobs more difficult, it can also enrich the school environment and hasten the assimilation of immigrant students. In fact, small ethnic minority groups have a larger incentive to adopt the majority culture and language as a means of interaction (Lazear, 1999; Maestri, 2017). Yet little empirical research exists on the effect of classroom ethnic diversity on native school performance other than a recent study by Maestri (2017), ${ }^{19}$ who finds that although ethnic diversity has no significant impact on native students' literacy scores, it does increase those of immigrant students, even after controls are included for ethnic composition and peers effects.

To construct our own measure of ethnic diversity across the foreign-born population in each class, we first adopt country of birth as a designator of cultural and ethnic identity (see Ottaviano and Peri, 2006; Constant et al., 2009; Alesina et al., 2016) and then calculate a diversity index based on the Hirschman-Herfindahl Index (Hirschman, 1964):

$$
D I V=1-\sum_{i} s_{i}^{2}
$$

where $s_{i}$ denotes the share of students born in country $i$ out of the total number of foreign-born students in each class. Hence, this index, which is bounded between a minimum of 0 for contexts with only one category and a maximum of 1 when the population is divided into an infinite number of categories, can be interpreted as the likelihood that two randomly selected immigrant students will not be born in the same country. DIV is a measure of fractionalization that considers all groups to be the same regardless of origin country characteristics. However, because students whose native language differs significantly from Italian may have lower school achievement and need a higher proportion of teacher time, we explore the role of the linguistic distance between the native language of immigrants and Italian. To do so, we create

\footnotetext{
${ }^{19}$ Both Dronkers and van der Velden (2012) and Braster and Dronkers (2013) provide useful discussions of this topic but neither attempts to identify any causal impact.
} 
an index of language dissimilarity (LDI) calculated as each class's mean on the Levenshtein linguistic distance index (taken from Adsera and Pytlikova, 2015). This index, produced by the Max Planck Institute for Evolutionary Anthropology, relies on the phonetic dissimilarity of words in two languages. The continuous index increases with the distance between languages. To formulate the index, linguists chose a core set of 40 everyday words that are most common across languages, expressed them in phonetic transcription (ASJP code) and then computed the number of steps needed to move from a word expressed in one language to that same word expressed in another (see Bakker et al., 2009, for methodological details). In our sample, the index ranges from 58 (for Spanish) and 102 (for Rwandan).

Not only do these two indices, the DIV and LDI, measure different dimensions of diversity, they are not necessarily correlated with immigrant share in the classroom. To illustrate, consider two classes with 20 students, 5 of whom are foreign born and suppose that all the foreign-born students in class one were born in Romania, and all those in class two were born in China. In both classes, the share of immigrants is 25 percent and the DIV is zero. However, because a neo-Latin language like Romanian is more similar to Italian than Mandarin, the LDI will be 61 in the first class and 100 in the second. Note that the two indices would be unaffected if the number of immigrants changed but not their composition. Likewise, if instead of being from Romania, the five immigrant students in class one were from Ecuador, Peru, El Salvador, Venezuela and Spain, then the DIV would jump to 0.84 because the ethnic diversity had increased, but the LDI would actually decrease to 58 because Spanish is closer to Italian than Romanian. To depict these points graphically, Figure 5.1 plots the LDI against the DIV for each class to reveal a mere 0.0802 linear correlation $(p$-value $=0.0103)$ between the two measures. Figure 5.2 then plots the DIV (left diagram) or LDI (right diagram) against the classroom immigrant share, demonstrating empirically that both measures capture class attributes other than immigrant concentration. ${ }^{20}$

[Figure 5.1]

[Figure 5.2]

\footnotetext{
${ }^{20}$ We have also tested whether there is any evidence of systematic sorting of native students across classes within each school with respect to either diversity or language dissimilarity, by regressing native test scores at entrance on the initial DIV or LDI, along the lines of what we did in section 4.2, and found no indication of systematic sorting. Detailed regression results are available upon request.
} 
We then run separate regressions for classes that are high (low) in either diversity (Table 5.3, top panel) or language dissimilarity (bottom panel) based on the DIV or LDI being above (below) the median. The results confirm the lack of any significant impact of immigrant concentration on literacy scores even in classes with high language dissimilarity and high cultural diversity (columns 1 and 2 - top and bottom panel). Even more interesting, our estimates show that despite no significant differences between classes with high and low diversity (columns 3 and 4, top panel), immigrant share does have a negative effect on native maths scores in classes with high language dissimilarity, but no effect when language dissimilarity is low (columns 3 and 4, bottom panel). The difference between the two immigrant share coefficients in classes with high and low linguistic dissimilarity is statistically significant, as we can reject the null hypothesis of equality with a $p$-value of 0.008 .

[Table 5.3]

Because this latter also suggests that the linguistic distance between foreign born and native students may play a key role in explaining immigrant peer effects, it also implies a potential channel through which immigrant students could adversely affect natives; namely, an externality from limited language proficiency that may be difficult for teachers to cope with when the immigrant group is diverse and linguistically distant. To investigate this conjecture more deeply, we run the same regressions further dividing our sample by student ability level (see Table 5.4). The results indicate that immigrant share only has a negative effect on low ability natives in classes with high linguistic dissimilarity (see column 3). High ability natives, in contrast, experience no effect even if the linguistic distance of their immigrant peers is high (see column 4). In panel B, we test whether the peer effect difference between high and low LDI classes holds in a non-linear setting by including immigrant share in each cohort as a regressor dummy for each quintile of the distribution (cf. Table 5.2). These results confirm that the negative immigrant effect comes entirely from the classes with high linguistic distance and a very high concentration of immigrants (top 20\%) and that it is larger for low ability natives.

[Table 5.4]

All these findings point not only to the importance of native-immigrant linguistic distance in explaining immigrant peer effects, but to the fact that cultural heterogeneity - as proxied by origin country-based diversity - plays no role. Nevertheless, linguistic distance could, in 
addition to signalling language difficulties, reflect other cultural traits capable of affecting educational achievement and driving the observed effect. In fact, a growing body of literature is demonstrating a clear positive correlation between different measures of cultural capital and educational attainment. For example, Figlio et al. (2016) find that students from societies with a long term orientation perform better than students from cultures that do not emphasize the importance of delayed gratification. Hence, to test whether linguistic distance reflects cultural distance, we correlate our measure of linguistic distance with several indices of cultural traits. Specifically, we consider Hofstede et al.'s (2010) six measurable dimensions of national culture: long-term orientation (the dimension used in Figlio et al. 2016), individualism, power distance, masculinity, uncertainty avoidance and indulgence. ${ }^{21}$ According to the definitions in Hofstede et al. (2010), the first, long-term orientation, is the cultural value that stands for the fostering of virtues oriented toward future rewards. Power distance describes the extent to which the less powerful members of institutions and organizations within a country expect and accept that power is distributed unequally. Uncertainty avoidance refers to the extent to which the members of a culture feel threatened by ambiguous or unknown situations. Individualism describes a society in which ties between individuals are loose (i.e. people are expected to look after themselves and their immediate family). Masculinity characterizes a society in which emotional gender roles are clearly distinct - men are supposed to be assertive, tough and focused on material success, while women are supposed to be modest, tender and concerned with quality of life. Indulgence concerns the good things in life, being free and following one's impulses as opposed to being restrained, feeling that life is hard, and believing that duty, not freedom, is the normal state of being. These dimensions, which are based on responses to questionnaires that allow an appraisal of the personal values dominant in each country, are all measured on indices ranging from 0 to $100 .^{22}$

In Figure 5.3, by plotting the index for each of these six cultural dimensions against percentiles of the linguistic distance index, we clearly demonstrate that linguistic distance is uncorrelated with any cultural dimension. This lack of correlation strongly implies that linguistic distance is truly capturing linguistic difficulties rather than proxying for unobservable cultural traits. In fact, linguistic distance affects the ease or difficulty with

\footnotetext{
${ }^{21}$ These variables are available in the spreadsheet "Six dimensions for website.xls (version 2015 12 08)" with additional data for Nepal and Sri Lanka in "Nonofficial VSM08 scores", all downloadable from www.geerthofstede.nl/dimensiondata-matrix in/

${ }^{22}$ For more details, see http://www.geerthofstede.nl/vsm-08.
} 
which immigrants learn Italian, it being easier to learn a language that is linguistically closer to the native one (Chiswick and Miller, 2005; Isphording and Otten, 2014).

\section{[Figure 5.3]}

Based on the previous finding, we expect the linguistic distance index to be correlated with immigrants' command of Italian but not with their general ability. Having no precise measure of immigrant knowledge of Italian, however, we proxy this latter with the literacy test scores at entrance. More specifically, in Table 5.5, we test the relation between linguistic distance and initial proficiency in literacy and maths by regressing, for each immigrant in the sample, the initial literacy (column 1) and maths (column 2) scores on the standardized Levenshtein index, as well as individual controls (age and gender) and cohort dummies. As the table shows, the linguistic distance index is negatively associated with Italian performance (a one standard deviation increase in linguistic distance is associated with a 0.14 standard deviation decrease in literacy scores) but not significantly related to performance in maths. The index thus appears to be capturing immigrants' actual proficiency in Italian and not other cultural or social dimensions that would have similarly affected maths scores. Nonetheless, although linguistic distance and literacy performance are correlated, a substantial fraction of the individual variability in test scores cannot be accounted for by language distance. In fact, the literacy regression in Table 5.5 has an R-squared of just 0.06 , indicating that $94 \%$ of the test score variation results from factors other than linguistic distance, age and gender.

[Table 5.5]

In Figure 5.4, therefore, we depict the extent of this test score variability, which occurs even among immigrants with similar levels of language dissimilarity, by showing the distribution of standardized test scores in literacy (left diagram) and maths (right diagram) over deciles of the linguistic distance distribution. In particular, the figure reports the value of the median (solid line) scores and plots the $25^{\text {th }}$ to $75^{\text {th }}$ percentiles (blue box) for immigrants in each decile of the linguistic distance distribution. These graphs not only reaffirm the lack of any correlation with maths and the negative association between linguistic distance and literacy scores (whose median values decrease over the deciles of the linguistic distance distribution) but also highlights the substantial test score variation at each level of linguistic distance. This latter suggests that the competences measured in the test do not simply reflect language proficiency but also other types of skills, such as more general cognitive ability. Hence, a researcher interested in isolating the role of language in determining immigrant peer effects 
may find linguistic distance to be a more appropriate measure than literacy test scores, which are also affected by other competences and may thus be confounded with a peer ability effect.

[Figure 5.4]

\section{Robustness checks and additional results}

\subsection{Class size adjustments}

Ballatore et al. (2018) show how conventional estimates of immigrant peer effects may underestimate the direct effect of immigrants on natives' achievements, due to the endogenous response of class size to immigrant concentration. In fact, even if the allocation of immigrants across classes within a school is orthogonal to the ability of their native and non-native peers, as suggested by our tests in section 4 , school principals may systematically assign immigrant students to smaller classes to help their learning process. Therefore, the estimated effect of immigrant peers would comprise of both the direct effect of immigrants on natives' learning outcomes, and of the indirect effect of a smaller class size. To clarify how our estimates should be interpreted, therefore, we directly test for any evidence of a systematic relationship between class size and the share of immigrants in the class, by running class -level regressions of class size on the share of immigrants in the class. The results, reported in column (1) of Table 6.1, show that there is no statistically significant relationship between these two variables.

[Table 6.1]

Additionally, to further investigate the role of class size, in columns (2) to (7) of Table 6.1 we have replicated our baseline results of Table 5.1, without including class size as a control variable. As expected, the exclusion of this variable from our specification does not significantly affect the estimates: all the coefficients of interest have the same sign and are very close in magnitude to those of our baseline specifications. ${ }^{23}$

\subsection{Effects on immigrants}

Our analysis has so far focused on native students only. However, the presence of foreignborn peers may also impact on the achievement of immigrant students. For instance,

\footnotetext{
${ }^{23}$ Results of Tables 5.2, 5.3, and 5.4 are also robust to the exclusion of class size from the set of control variables. Detailed regression tables are available upon request.
} 
Schneweiss (2015) shows that a higher share of immigrant peers negatively affects immigrant students' educational outcomes in Austria, in terms of both grade repetition and choice of school track, and Haelermans and Heers (2016) find similar results for the Netherlands. In this section, we therefore investigate whether the share of immigrants in a class affects the test scores of immigrants themselves in our setting. It should be noted, however, that even if the share of immigrants in our sample is relatively high (18\%), this amounts to just 2,600 nonnative students, and therefore estimates may not be very precise.

In fact, our estimates of peer effects for immigrants are quite inconclusive: we find no evidence of a statistically significant impact of the share of foreign students in the class on neither literacy nor maths test scores of their non-native peers, irrespective of their ability, as we show in Table 6.2.

[Table 6.2]

Likewise, the share of immigrants in the class has no effect on the test scores of foreign students, neither in classes characterized by high diversity nor in those where immigrants have a more homogenous ethnic background (top panel of Table 6.3).

\section{[Table 6.3]}

Interestingly, however, the bottom panel of Table 6.3 suggests that a higher immigrant concentration may have positive effects on the maths test scores of foreign students, provided that the immigrants students in the class have a low average linguistic distance from Italian. Table 6.4 indicates that this positive result is driven by high ability foreign students, who appear to benefit from a higher presence of foreign-born peers in classes with low linguistic distance.

[Table 6.4]

\subsection{Discussion of additional channels}

While we have underlined the important role played by the linguistic distance between foreign born and native students in explaining immigrant peer effects, there are other dimensions of heterogeneity in the immigrant group that may potentially affect the impact of immigrant concentration in the class. For example, Bossavie (2018) finds that the duration of stay of foreign-born children in the host country plays a key role in explaining immigrant peer 
effects in the Netherlands. His results in fact show that, while immigrant classmates who have already been in the country for some time have virtually no effect on natives' achievement, a higher concentration of recent immigrants, who likely require greater attention from teachers, has a significant negative impact on natives' test scores. Along the same lines, these results suggest that another important determinant of immigrants' educational attainment, as well as of their potential impact on native peers, may be the degree of socio-economic integration experienced by their family members, or by their ethnic community at large (see e.g. Gang and Zimmermann, 2000). Unfortunately, our data do not have information on age-atmigration or on parental characteristics of individual students to directly test the heterogeneity of spillover effects of immigrant classmates along these dimensions. However, we can compute the average duration of stay in Italy and the average employment rate of immigrants from each origin group in Lombardy, pooling yearly data from the Italian Labour Force Survey for the period 2009-2012. We then match this aggregate information with each immigrant student based on his country of birth, which allows us to distinguish between classes characterized by a high or low average migration seniority or labour market integration.

We report in Table 6.5 results from separate regressions for the subsample of classes characterised by a low (columns 1, 2, 3) or high (columns 4, 5, 6) average employment rate (Panel A) or duration of stay (Panel B), where "high" or "low" are defined as above or below the median value for all immigrants in Lombardy.

[Table 6.5]

Our estimates suggest that immigrant peer effects are indeed heterogeneous according to the degree of labour market integration of the community of origin of immigrant students: the impact of immigrant share is negative and statistically significant only in classes characterised by low average employment rate and, consistently with our previous results, this effect is larger for low ability natives. The heterogeneity by length of stay is, instead, less revealing. However, including the average class-level measures of immigrant communities' employment rate or years since migration in Italy as additional control variables in our baseline regressions of Panel A in Table 5.4, has virtually no effect on the size or on the statistical significance of our coefficient of interest, as we show in Table 6.6.

[Table 6.6] 
These results therefore indicate that language distance plays an independent role in determining the sign and size of immigrant peer effects, over and beyond the labour market integration of the ethnic networks of immigrant students.

\section{Conclusions}

Despite concern in many advanced countries that the lower school performance of the increasing shares of immigrant may be detrimental to native students' educational achievement, the empirical evidence of such spillover effects is scant, with most studies reporting little or no effect. We therefore test for such effects not only in a country experiencing a sizable increase in immigrant population but, more particularly, in its vocational training institutions, which attract both a disproportionate share of immigrant students and the most disadvantaged segment of the native student population, who may be more vulnerable to peer characteristics. Our analysis, based on a unique administrative dataset on the universe of students in vocational institutions in Italy's largest region, identifies the effect of immigrant peers on native test scores by relying on random variation in students across classes and across adjacent cohorts within schools. These data, by allowing several validation tests of our identifying assumptions and enabling the implementation of value added models, both minimize the measurement error-induced attenuation bias typical of survey data and reduce the omitted variable bias in the modelling of the education production function.

We find that although the presence of immigrant students in the classroom has no effect on natives' literacy scores, it does negatively affect their maths scores. Nonetheless, even in our disadvantaged context, these effects are quantitatively small on average, although larger for native students in the lowest half of the ability distribution. More specifically, a one standard deviation increase in classroom immigrant share (i.e. 15 percentage points) results in a $7.6 \%$ of a standard deviation reduction in mean maths scores, an effect that increases to $12 \%$ of a standard deviation for low ability native students. Our results also indicate that these effects are strongly non-linear, only arise in classes with a high (top 20\%) immigrant concentration, and are driven by classes characterized by a high average linguistic distance between foreignborn and native students. In these latter, the negative effect is even larger: a one standard 
deviation increase in immigrant share leads to $19 \%$ of a standard deviation reduction in maths scores for low ability natives.

Unlike many other papers that fail to find any significant adverse impact of immigrant peers on native students, our analysis indicates the potential for some negative peer effects. We recognize, however, that our results may be due to the particular setting analysed in which the vast majority of native students fall into the bottom part of the national ability distribution (see Figure 2.2). Our mean effects should thus be interpreted as the effect on the mean low ability native student rather than that on the mean native student in general. Moreover, in terms of magnitude, our mean estimates indicate that immigrant peer effects are quite small relative to other peer effects studied in the literature. For instance, Ammermueller and Pischke (2009) find that a one standard deviation change in their peer variable (the average number of books in the home of classroom peers) leads to a $17 \%$ of a standard deviation increase in reading test scores, ${ }^{24}$ an effect that is 2.3 times larger than ours. Another useful way to interpret the size of our estimated effects is to compare them with the estimates of class-size effects. Angrist and Lavy (1999), for example, estimate that a one standarddeviation increase in class size among Israeli fifth graders reduces maths test scores by $14.4 \%$ of a standard deviation, ${ }^{25}$ which corresponds to about twice our estimated effect. As regards the mechanisms through which these effects operate, we find that ethnic diversity plays no role in the effect; rather, the results are driven by classes in which the average linguistic distance between immigrants and natives is high.

Taken together, our estimates indicate that the impact of immigrant concentration in a classroom is negligible, even in the generally disadvantaged context of vocational training. This observation suggests that the widespread perception of an increasing number of immigrant students imposing negative peer effects on their native-born peers may not be empirically grounded. On the other hand, we do show that problems may arise when the immigrant share is particularly large and the linguistic distance high. Our findings thus seem to imply that native students could benefit from a more even distribution of foreign-born students across schools, achieved perhaps through such measures as residential desegregation policies. In addition, given our evidence that linguistic distance matters, investing more

\footnotetext{
${ }^{24}$ See Ammermueller and Pischke (2009), Table 8, last row of column 5.

${ }^{25}$ Angrist and Lavy (1999) report a 2SLS coefficient of -0.230 for the effect of an additional student on average maths scores in the class for fifth graders (Table IV, column 8). We divide this coefficient by 9.6, the standard deviation of the fifth graders' maths scores (also reported in Table IV), and multiply by 6 , the standard deviation of the fifth grade class size reported in Appendix 1, Panel A.
} 
resources for linguistic support to immigrant students might help mitigate the potentially disruptive effects of high immigrant concentrations in schools. 


\section{References}

Adsera, A. and M. Pytlikova (2015). "The Role of Literacy in Shaping International Migration.” Economic Journal, 125: F49-F81.

Alesina, A., and E. La Ferrara. (2005). "Ethnic Diversity and Economic Performance." Journal of Economic Literature 43 (3): 762-800.

Alesina, A., Harnoss, J. and Rapoport, H. (2016). "Birthplace diversity and economic prosperity." Journal of Economic Growth 21 (2): 101-138.

Ammermueller, A., Pischke J. S. (2009). "Peer Effects in European Primary Schools: evidence from the Progress in International Reading Literacy Study." Journal of Labor Economics, 27: 315-348.

Anelli, M., Shih, K., and Williams, K. (2017). "Foreign Peer Effects and STEM Major Choice." IZA Discussion Paper No. 10743.

Angrist, J. D., and Lang, K. (2004). "Does School Integration Generate Peer Effects? Evidence from Boston's METCOP.” American Economic Review, 94(5), 1613-1634.

Angrist, J.D. and Lavy, V. (1999). "Using Maimonides' Rule to Estimate the Effect of Class Size on Scholastic Achievement." Quarterly Journal of Economics, 114 (2), 533-575

Auerbach, A. and P. Oreopoulos (1999). "Analyzing the Fiscal Impact of U.S. Immigration.” American Economic Review, 89, 176-180.

Aydemir A. and Borjas, G.J. (2010). "A Comparative Analysis of the Labor Market Impact of International Migration: Canada, Mexico and the United States." Journal of the European Economic Association, 5 (4), 663-708.

Ballatore, R.M., Fort, M. and Ichino, A. (2018) "The Tower of Babel in the Classroom: Immigrants and Natives in Italian Schools." Journal of Labor Economics, forthcoming.

Bakker, D., Müller, A., Velupillai, V., Wichmann, S., Brown, C.H., Brown, P., Egorov, D., Mailhammer, A., Grant, A. and Holman, E.W. (2009). "Adding Typology to Lexicostatistics: a combined approach to literacy classification.” Linguistic Typology, 13(1), 69-181.

Betts, J.R. \& Fairlie, R.W. (2003). "Does Immigration Induce 'Native Flight' from Public Schools into Private Schools?" Journal of Public Economics, 87(5-6), 987-1012.

Borjas, G.J. (2003). "The Labor Demand Curve Is Downward Sloping: reexamining the impact of immigration on the labor market." Quarterly Journal of Economics, 118, $1335-1374$.

Bossavie, L. (2018). "The Effect of Immigration on Natives' Performance at School: Does Length of Stay in the Host Country Matter?" Journal of Human Resources, forthcoming.

Braga, M., Checchi, D. and Meschi, E. (2013). "Educational Policies in a Long Run Perspective.” Economic Policy, 28(73), 45-100.

Braster, S. and Dronkers, J. (2013). "The Positive Effects of Ethnic Diversity in Class on the Educational Performance of Pupils in a Multi-Ethnic European Metropole." CReAM 
Discussion Paper, No 18/13, Centre for Research and Analysis of Migration, Department of Economics, University College London, London.

Brunello, G. and Rocco, L. (2013). "The Effect of Immigration on the School Performance of Natives: cross country evidence using PISA test scores." Economics of Education Review, 32(C), 234-246.

Brunello, G. and De Paola, M. (2017). "School Segregation of Immigrants and its Effects on Educational Outcomes in Europe.” EENEE (European Expert Network on Economics of Education) Report N.30.

Burke, M.A. and Sass, T.R. (2013). "Classroom Peer Effects and Student Achievement." Journal of Labor Economics, 31(1), 51-82.

Card, D. (2001). "Immigrant Inflows, Native Outflows and the Local Labor Market Impacts of Immigration.” Journal of Labor Economics, 19, 22-64.

Card, D. (2005). "Is the New Immigration Really So Bad?" Economic Journal, 115, F300F323.

Card, D. and Rothstein, J. (2007). "Racial Segregation and the Black-White Test Score Gap." Journal of Public Economics, 91(11-12), 2158-2184.

Carlana, M., La Ferrara, E. and Pinotti, P. (2017) "Goals and Gaps: Educational Careers of Immigrant Children”, CEPR Discussion Paper No. DP12538.

Cascio, E.U. and Ethan G. Lewis, (2012). "Cracks in the Melting Pot: Immigration, School Choice, and Segregation.” American Economic Journal: Economic Policy, 4(3), 91117.

CEDEFOP (2014). "Vocational Education and Training in Italy." European Centre for the Development of Vocational Training.

Contini, D. (2013). "Immigrant Background Peer Effect in Italian Schools." Social Science Research, 42 (4), 1122-1142.

Chiswick, B.R., and Miller, P.W. (2005). "Linguistic Distance: a quantitative measure of the distance between English and other literacies." Journal of Multilingual and Multicultural Development, 26(1), 1-11.

Constant, A. F., Gataullina, L. and Zimmermann, K. F. (2009). "Ethnosizing Immigrants." Journal of Economic Behaviour \& Organization, 69(3), 274-287.

Dronkers, J. and R. van der Velden (2012). "Positive But Also Negative Effects of Ethnic Diversity in Schools on Educational Performance? An empirical test using crossnational PISA data". In: M. Windzio (ed.), Integration \& Inequality in Educational Institutions, Springer, Dordrecht.

Duflo, E., Dupas, P. and Kremer, M. (2011). "Peer Effects, Teacher Incentives, and the Impact of Tracking: evidence from a randomized evaluation in Kenya." American Economic Review, 101(5), 1739-74.

Dustmann, C., Frattini, T. and Preston, I. (2013). "The Effect of Immigration along the Distribution of Wages." Review of Economic Studies, 80 (1), 145-173.

Dustmann, C. and T. Frattini (2014). "The Fiscal Effects of Immigration to the UK." Economic Journal, 124 (580), F593-F643. 
Eichhorst, W. (2015). "Does vocational training help young people find a (good) job?.” IZA World of Labor, 112 doi: 10.15185/izawol.112.

Farrè L., Ortega, F. and Ryuichi, T. (2015). "Immigration and School Choices in the Midst of the Great Recession.” IZA Discussion Paper, No. 9234.

Figlio, D., Giuliano, P., Özek, U. and Sapienza, P. (2016). "Long-Term Orientation and Educational Performance.” NBER Working Paper, No. 22541.

Friesen, J. and Krauth (2011). "Ethnic Enclaves in the Classroom." Labour Economics, 18(5), 656-663.

Gang, I., and Zimmermann, K. (2000). "Is Child like Parent? Educational Attainment and Ethnic Origin". The Journal of Human Resources, 35(3), 550-569.

Geay, C., McNally, S. and Telhaj, S. (2013). "Non-Native Speakers of English in the Classroom: what are the effects on pupil performance?" Economic Journal, 123, F281-F307.

Gould, E. D., Lavy, V., and Paserman, M. D. (2009). "Does Immigration Affect the LongTerm Educational Outcomes of Natives? Quasi-experimental evidence." Economic Journal, 119, 1243-1269.

Gorgorió, N., and Planas, N. (2001). "Teaching Mathematics in Multilingual Classrooms." Educational Studies in Mathematics, 47(1), 7-33.

Haelermans, C., and Heers, M. (2017). "The effects of immigrant student concentration on educational outcomes of native and immigrant students.", Tier Working Paper No. 2017- 16.

Hanushek, E., Kain, J., Markman, J. and Rivkin, S. (2003). "Does peer ability affect student achievement?" Journal of Applied Econometrics, 18(5), 527-544.

Hardoy, I. and Schøne, P. (2013). "Does the Clustering of Immigrant Peers Affect the School Performance of Natives?" Journal of Human Capital, 7(1), 1-25.

Hofstede, G., Hofstede, G.J. and Minkov, M. (2010). Cultures and Organizations: Software of the Mind: intercultural cooperation and its importance for survival, 3rd ed. McGraw-Hill, New York.

Hoxby, C. M. (2000). "Peer Effects in Classroom: learning from gender and race variation." NBER Working Paper, No. 7867.

Hunt, J. (2016). "The Impact of Immigration on the Educational Attainment of Natives." Journal of Human Resources, 0115-6913R1.

ISFOL (2008). "Thematic Overview: vocational education and training - Italy."

Isphording, I. and Otten, S. (2014). "Linguistic Barriers in the Destination Literacy Acquisition of Immigrants.” Journal of Economic Behavior \& Organization, 105, 3050 .

Jensen, P. (2015). "Immigrants in the Classroom and Effects on Native Children." IZA World of Labor, 194. 
Jensen, P. and Rasmussen, A.W. (2011). "The Effect of Immigrant Concentration in Schools on Native and Immigrant Children's Reading and Math Skills." Economics of Education Review, 30(6), 1503-1515.

Lavy, V., Paserman, M. D. and Schlosser, A. (2012), "Inside the Black Box of Ability Peer Effects: Evidence from variation in the proportion of low achievers in the classroom." Economic Journal, 122, 208-237.

Lavy, V., Silva, O. and Weinhardt, F. (2012): "The Good, the Bad, and the Average: Evidence on Ability Peer Effects in Schools." Journal of Labor Economics, 30(2), 367-414.

Lavy, V. and Schlosser, A. (2011). "Mechanisms and Impacts of Gender Peer Effects at School." American Economic Journal: Applied Economics, 3(2), 1-33.

Lazear, E. P. (1999). “Culture and Literacy.” Journal of Political Economy, 107(6). S95S126.

Lazear, E.P. (2001). "Educational Production.” Quarterly Journal of Economics, 116(3), 777 803.

Maestri, V. (2017). "Can Ethnic Diversity Have a Positive Effect on School Achievement?" Education Economics, 25(3), 290-303.

Micklewright, J., Schnepf, S. and Silva, P. (2012). "Peer Effects and Measurement Error: the impact of sampling variation in school survey data (evidence from PISA)". Economics of Education Review, 31(6), 1136-1142.

OECD (2015). "Immigrant Students at School: easing the journey towards integration". OECD Publishing, Paris. DOI: http://dx.doi.org/10.1787/9789264249509-en

Ohinata, A. and van Ours, J.C. (2013). "How Immigrant Children Affect the Academic Achievement of Native Dutch Children." Economic Journal, 123, F308-F331.

Ottaviano, G. and Peri, G. (2006). "The Economic Value of Cultural Diversity: evidence from U.S. cities.” Journal of Economic Geography, 6(1), 9-44.

Ottaviano, G. and Peri, G. (2012). "Rethinking the Effects of Immigration on Wages." Journal of the European Economic Association, 10, 152-197.

Preston, I. (2014). "The Effect of Immigration on Public Finances.” Economic Journal, 12, F569-F592.

Putnam, R.D. (2007). "E pluribus unum: Diversity and Community in the Twenty-First Century." Scandinavian Political Studies, 30(2), 137-174.

Ríordáin, M., and O'Donoghue, J. (2009). "The Relationship between Performance on Mathematical Word Problems and Literacy Proficiency for Students Learning through the Medium of Irish.” Educational Studies in Mathematics, 71(1), 43-64.

Sacerdote, B. (2011). "Peer Effects in Education: how might they work, how big are they and how much do we know thus far?" Handbook of the Economics of Education, 3, 249277.

Schnepf, S.V. (2007). "Immigrants' Educational Disadvantage: an examination across ten countries and three surveys." Journal of Population Economics, 20, 527-545. 
Schneeweis, N. (2015). "Immigrant Concentration in Schools: Consequences for Native and Migrant Students," Labour Economics, 35, 63- 76.

Todd, P. and Wolpin, K.I. (2003). "On the Specification and Estimation of the Production Function for Cognitive Achievement.” Economic Journal, 113(485), F3-F33.

Todd, P. and Wolpin, K.I. (2007). "The Production of Cognitive Achievement in Children: home, school, and racial test score gaps.” Journal of Human Capital, 1(1), 91-136.

Tonello, M. (2016). "Peer Effects of Non-native Students on Natives' Educational Outcomes: mechanisms and evidence." Empirical Economics, 51(1), 383-414. 


\section{Figures}

Figure 2.1: Share of foreign-born students, by school track: Lombardy and Italy

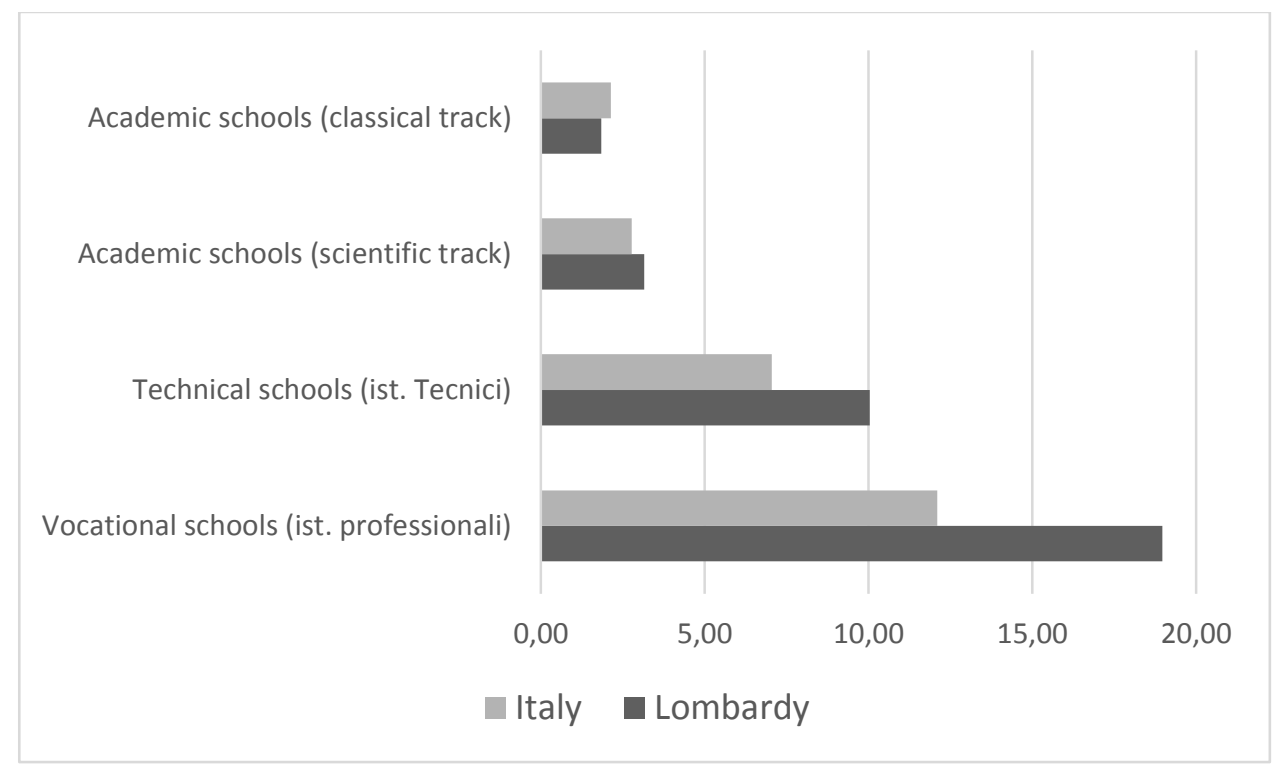

Source: Open Data, MIUR, 2012

Figure 2.2: Share of students in PISA levels, by track

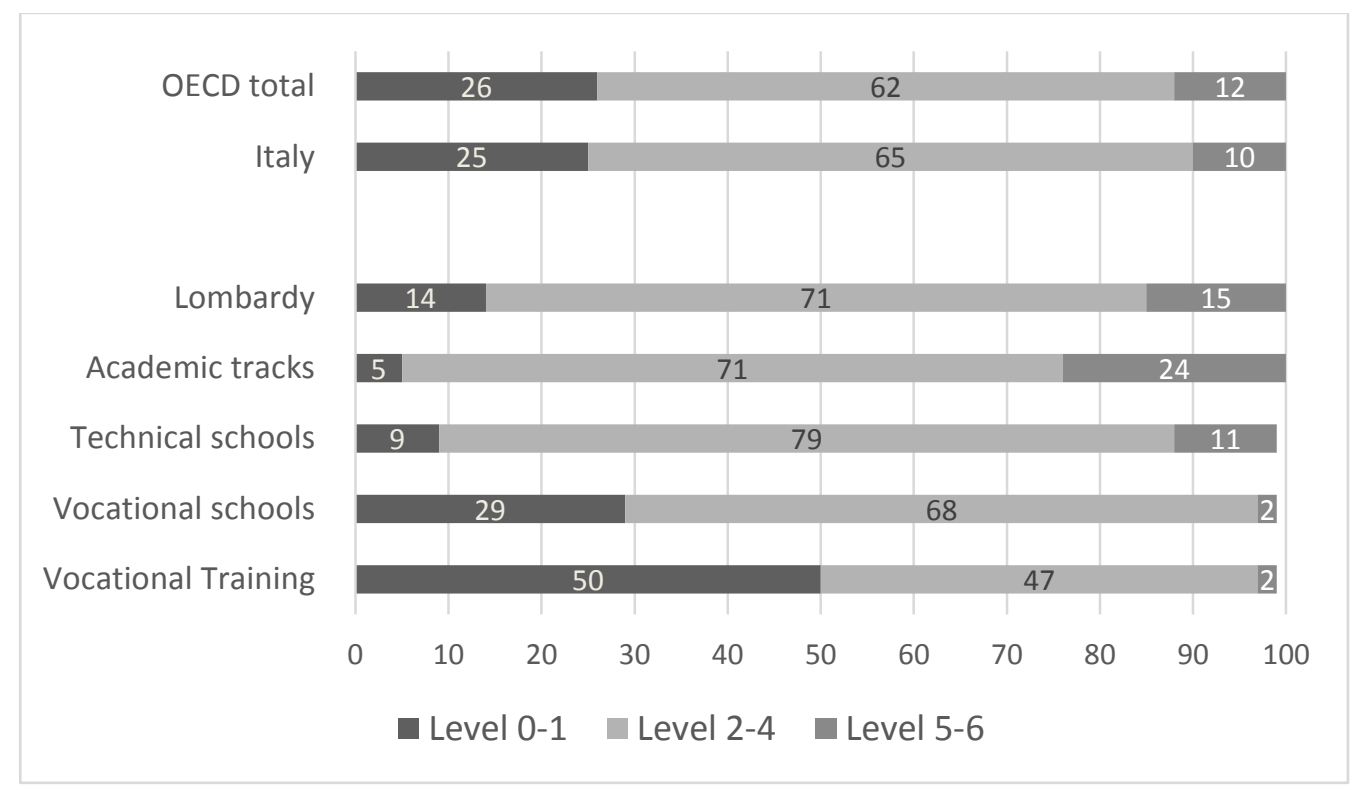

Source: PISA, 2012 
Figure 5.1: Correlations between our language dissimilarity index (LDI) and ethnic diversity index (DIV)

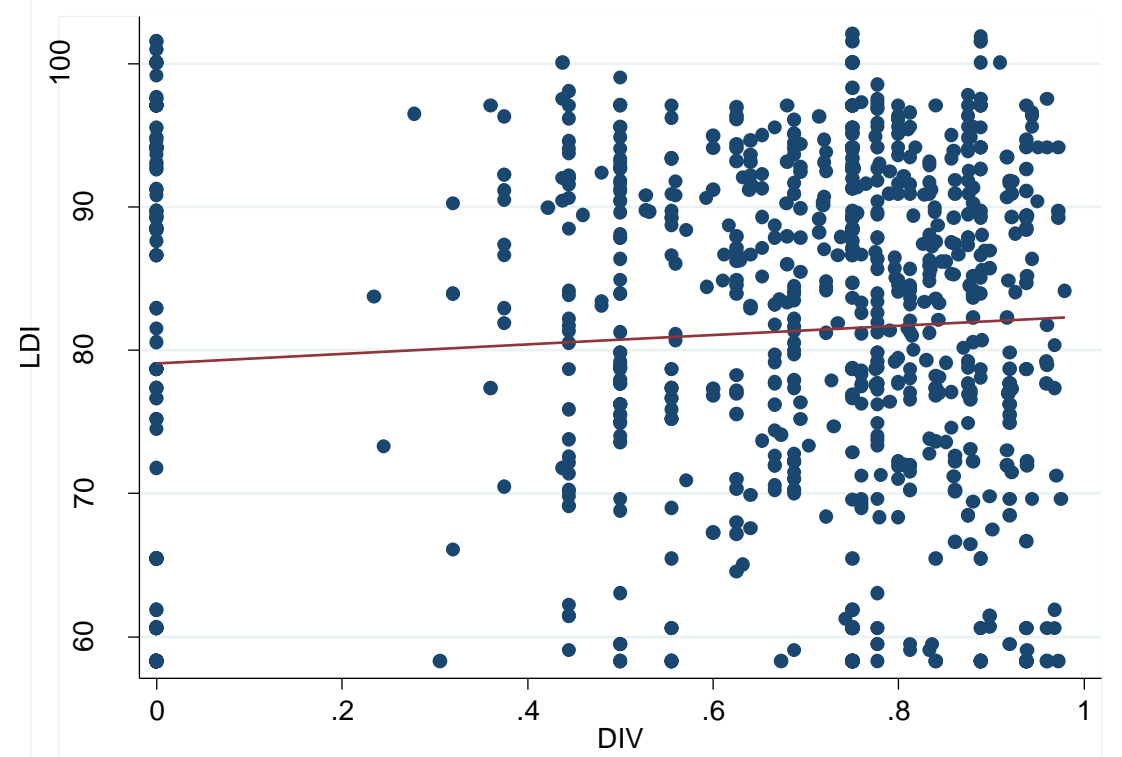

Note: The figure plots our linguistic distance index (LDI) against our diversity index (DIV). The LDI is each class's mean on the Levenshtein linguistic distance index; the DIV is equal to 1 minus the HirschmanHerfindahl index, with groups defined based on immigrant country of birth. 
Figure 5.2: Correlation between the classroom immigrant share and the ethnic diversity and language dissimilarity indexes
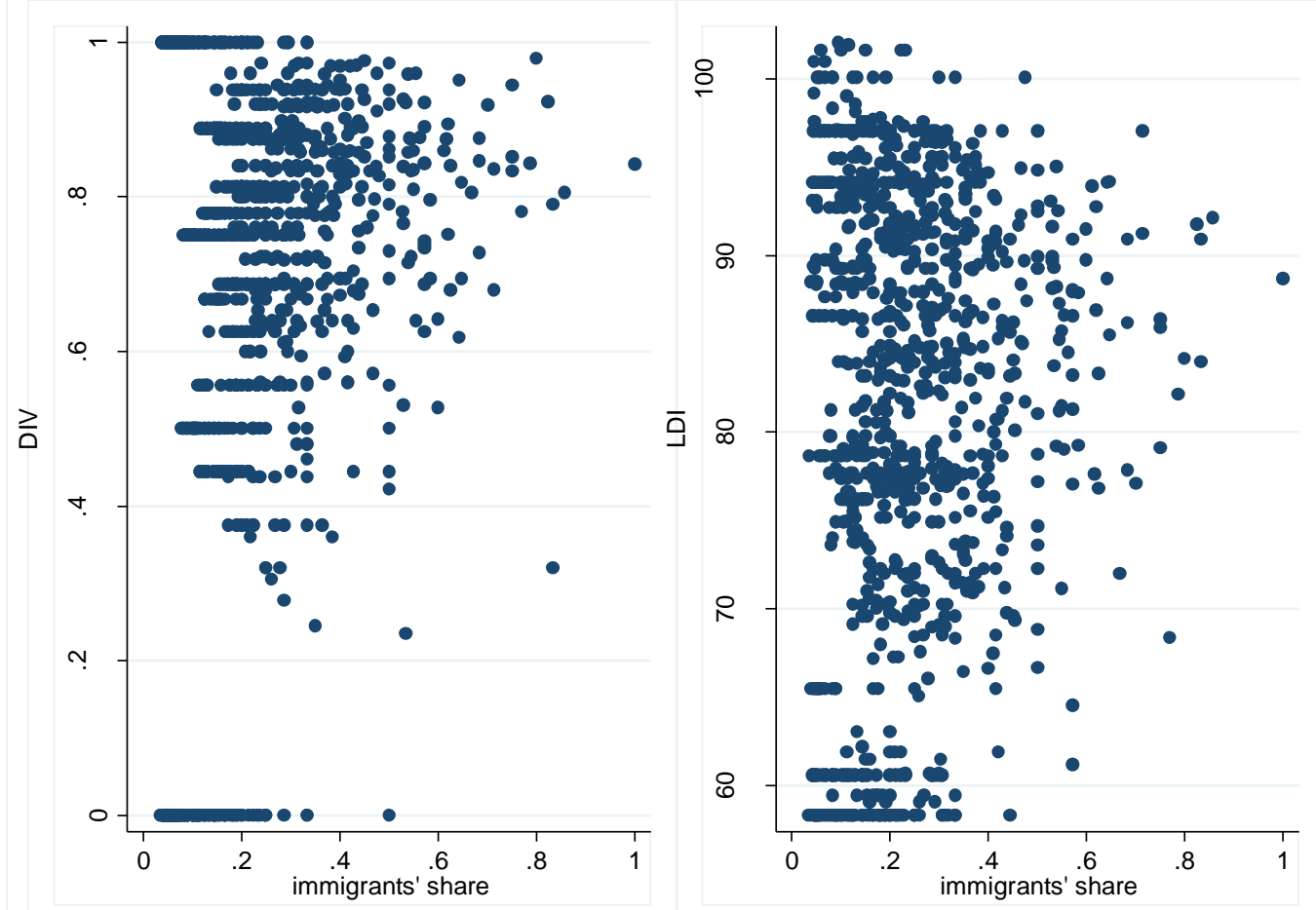

Note: The left- and right-hand diagrams plot the classroom immigrant share (horizontal axis) against the diversity index (DIV) and linguistic distance index (LDI), respectively. The LDI is each class's mean on the Levenshtein index; the DIV is equal to 1 minus the Hirschman-Herfindahl index, with groups defined based on immigrant country of birth. 
Figure 5.3: Correlation between the Levenshtein index of linguistic distance and other cultural dimensions
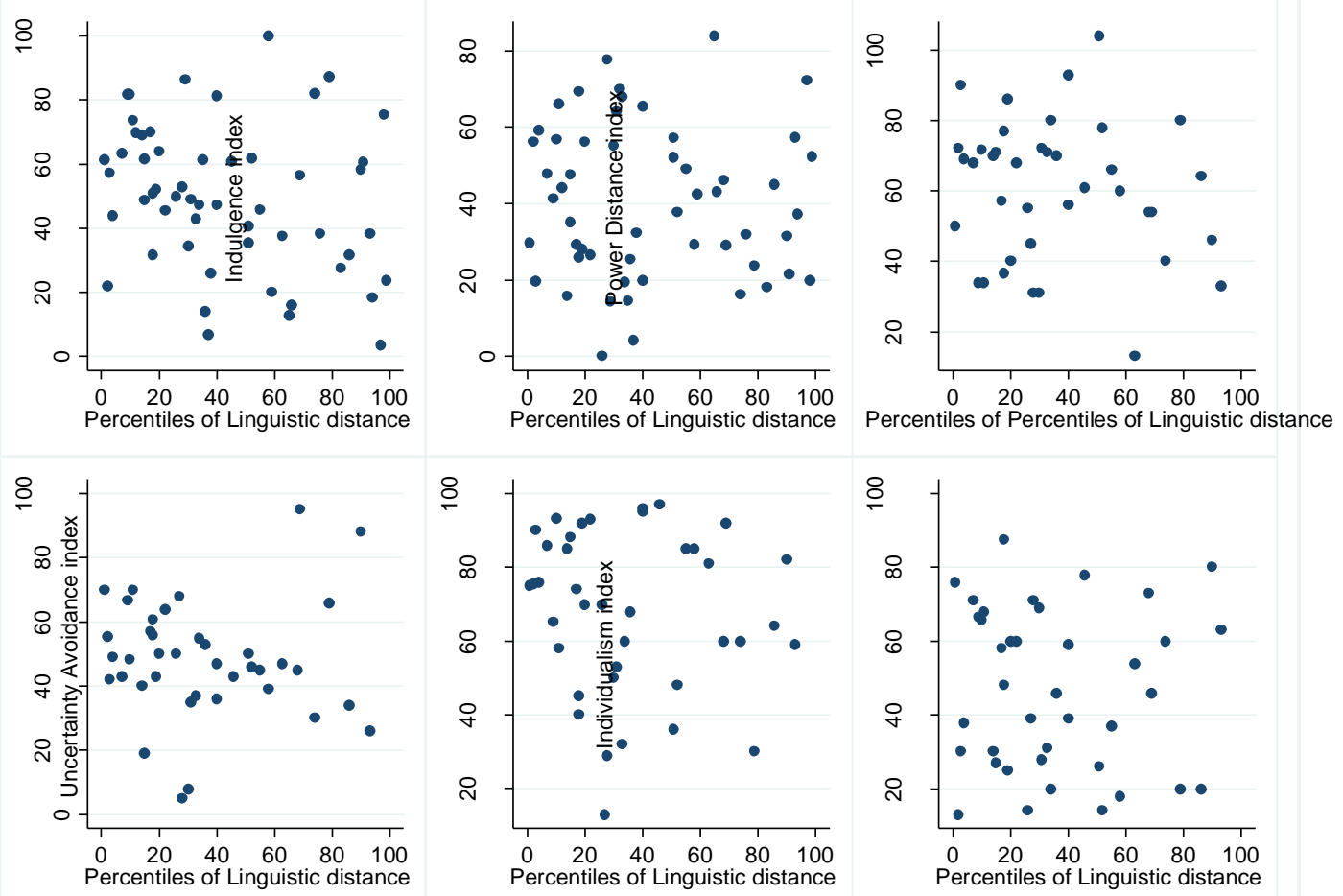

Note: The figure plots the Levenshtein index percentiles against Hofstede et al.'s (2010) six national culture dimension: individualism, power distance, masculinity, uncertainty avoidance, long-term orientation and indulgence. 
Figure 5.4: Box plots of the immigrants' standardized literacy and maths scores over the deciles of the Levenshtein index distribution
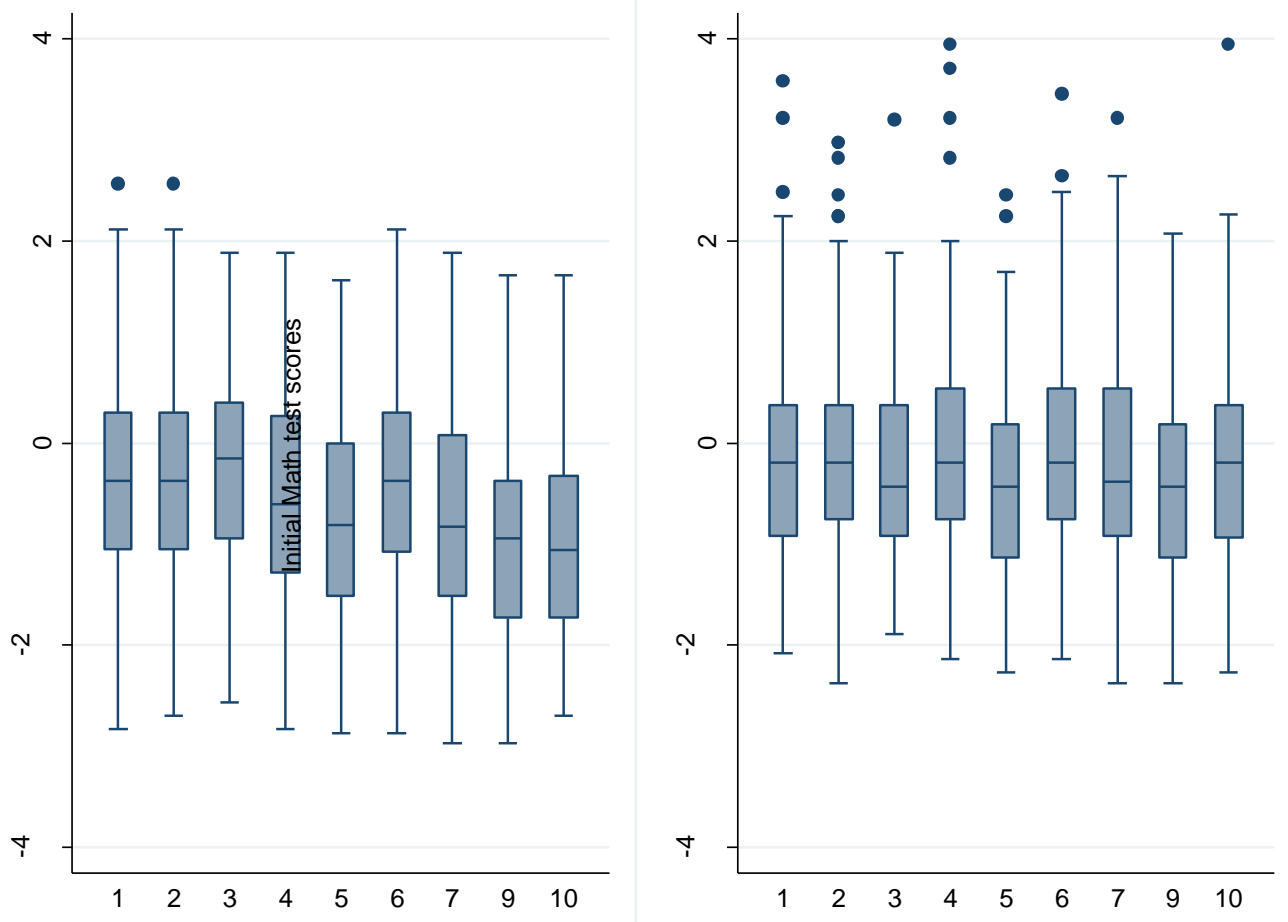

Note: The figure box plots the $25^{\text {th }}$ to $75^{\text {th }}$ percentiles (blue box), together with median value (solid blue line) of the immigrants' standardized test scores in literacy (left diagram) and maths (right diagram) over deciles of the the Levenshtein index distribution. The whisker ends are defined as the lowest datum still being within 1.5 IQR of the lower quartile, and the highest datum still being within 1.5 IQR of the upper quartile. 


\section{Tables}

Table 2.1: Summary statistics

\begin{tabular}{lccccc}
\hline \hline & N & Mean & SD & p25 & p75 \\
\hline Foreign born & & & & & \\
Female & 14434 & 0.18 & 0.38 & 0 & 0 \\
Age & 14434 & 0.44 & 0.50 & 0 & 1 \\
& 14434 & 17.76 & 0.95 & 17 & 18 \\
Share of foreign born per class & & & & & \\
\# of classes per school & 1244 & 0.19 & 0.15 & 0.08 & 0.28 \\
Class size & 1244 & 3.53 & 2.15 & 2 & 5 \\
Share of female per class & 1244 & 17.89 & 4.39 & 15 & 21 \\
& 1244 & 0.40 & 0.39 & 0 & 0.8 \\
Std (entrance) test score in maths - natives & & & & & \\
Std (entrance) test score in maths - immigrants & 11817 & 0.07 & 0.99 & -0.68 & 0.75 \\
Std (entrance) test score in literacy - natives & 11804 & -0.19 & 0.96 & -0.92 & 0.37 \\
Std (entrance) test score in literacy - immigrants & 2599 & -0.16 & 0.93 & -0.41 & 0.81 \\
\hline \hline
\end{tabular}

Note: The table reports the number of observations, means, standard deviations, and $25^{\text {th }}$ and $75^{\text {th }}$ percentiles for selected characteristics of the students, classes and schools in our sample.

Table 4.1: Distribution of $p$-values for Pearson $X^{2}$ tests of independence between immigrant background and classroom assignment within each school, by cohort

\begin{tabular}{lcccccccc}
\hline \hline & $5 \%$ & $10 \%$ & $11 \%$ & $25 \%$ & $50 \%$ & $75 \%$ & $90 \%$ & $95 \%$ \\
\hline $\mathbf{2 0 0 9}$ & 0.025 & 0.036 & 0.051 & 0.171 & 0.521 & 0.737 & 0.916 & 0.963 \\
$\mathbf{2 0 1 0}$ & 0.016 & 0.052 & 0.058 & 0.140 & 0.425 & 0.738 & 0.912 & 0.970 \\
\hline \hline
\end{tabular}

Note: The null hypothesis is that students are randomly assigned to classrooms. The test is conducted in each school which comprises of more than one classroom per cohort. 
Table 4.2: Sorting of native students into schools and classes.

\begin{tabular}{|c|c|c|c|c|}
\hline Dep. var.: natives' test scores (at entrance) & $\begin{array}{c}(1) \\
\text { Literacy }\end{array}$ & $\begin{array}{c}(2) \\
\text { Maths }\end{array}$ & $\begin{array}{c}(3) \\
\text { Literacy }\end{array}$ & $\begin{array}{c}(4) \\
\text { Maths } \\
\end{array}$ \\
\hline & \multicolumn{4}{|c|}{ Panel A: linear effects } \\
\hline Initial immigrant share & $\begin{array}{c}-0.346 * * * \\
(0.064)\end{array}$ & $\begin{array}{c}-0.207 * * * \\
(0.069)\end{array}$ & $\begin{array}{l}-0.129 \\
(0.111)\end{array}$ & $\begin{array}{l}-0.181 \\
(0.116)\end{array}$ \\
\hline Other controls & Yes & Yes & Yes & Yes \\
\hline School fixed effects & No & No & Yes & Yes \\
\hline
\end{tabular}

\begin{tabular}{|c|c|c|c|c|}
\hline Observations & 12,410 & 12,396 & 12,410 & 12,396 \\
\hline & \multicolumn{4}{|c|}{ Panel B: non-linear effects } \\
\hline $\begin{array}{l}\text { IMMSHARE quintile } \\
2^{\text {nd }}\end{array}$ & $\begin{array}{l}-0.006 \\
(0.024)\end{array}$ & $\begin{array}{c}0.022 \\
(0.026)\end{array}$ & $\begin{array}{c}0.010 \\
(0.029)\end{array}$ & $\begin{array}{c}0.028 \\
(0.030)\end{array}$ \\
\hline $3^{\text {rd }}$ & $\begin{array}{c}-0.074 * * * \\
(0.025)\end{array}$ & $\begin{array}{c}-0.055^{* *} \\
(0.027)\end{array}$ & $\begin{array}{l}-0.023 \\
(0.033)\end{array}$ & $\begin{array}{l}-0.010 \\
(0.034)\end{array}$ \\
\hline $4^{\text {th }}$ & $\begin{array}{c}-0.139 * * * \\
(0.026)\end{array}$ & $\begin{array}{c}-0.107 * * * \\
(0.028)\end{array}$ & $\begin{array}{l}-0.003 \\
(0.037)\end{array}$ & $\begin{array}{l}-0.028 \\
(0.039)\end{array}$ \\
\hline $5^{\text {th }}$ & $\begin{array}{c}-0.124 * * * \\
(0.029)\end{array}$ & $\begin{array}{c}-0.057 * \\
(0.031)\end{array}$ & $\begin{array}{l}-0.067 \\
(0.046)\end{array}$ & $\begin{array}{l}-0.009 \\
(0.048)\end{array}$ \\
\hline Other controls & Yes & Yes & Yes & Yes \\
\hline School fixed effects & No & No & Yes & Yes \\
\hline Observations & 12,410 & 12,396 & 12,410 & 12,396 \\
\hline
\end{tabular}

Note: Panel A reports the estimated regression coefficients of the classroom immigrant share at the beginning of the first school year on natives' standardized literacy (columns 1 and 3) and maths (columns 2 and 4) scores in the entrance exams. All regressions include controls for student age, gender, class size, share of females in the class and cohort dummies. Columns 1 and 2 exclude controls for school fixed effects, while columns 3 and 4 include them. Panel B presents the estimated coefficients of different quintiles of the classroom immigrant share (with the first quintile as the omitted variable). Robust standard errors (adjusted for clustering at the class level) are in parentheses, $* * * p<0.01, * * p<0.05, * p<0.1$ 
Table 4.3: Sorting of immigrant students into schools and classes.

\begin{tabular}{|c|c|c|c|c|}
\hline Dep. var.: immigrants' test scores (at entrance) & $\begin{array}{c}(1) \\
\text { Literacy }\end{array}$ & $\begin{array}{c}(2) \\
\text { Maths } \\
\end{array}$ & $\begin{array}{c}(3) \\
\text { Literacy }\end{array}$ & $\begin{array}{c}(4) \\
\text { Maths } \\
\end{array}$ \\
\hline & \multicolumn{4}{|c|}{ Panel A: linear effects } \\
\hline Initial immigrant share & $\begin{array}{c}-0.475^{* * *} * \\
(0.111)\end{array}$ & $\begin{array}{c}-0.066 \\
(0.110)\end{array}$ & $\begin{array}{c}-0.212 \\
(0.208)\end{array}$ & $\begin{array}{c}0.027 \\
(0.197)\end{array}$ \\
\hline Other controls & Yes & Yes & Yes & Yes \\
\hline School fixed effects & No & No & Yes & Yes \\
\hline Observations & 2,753 & 2,759 & 2,753 & 2,759 \\
\hline
\end{tabular}

$2^{\text {nd }}$
$3^{\text {rd }}$
$4^{\text {th }}$
$5^{\text {th }}$

Panel B: non-linear effects

$(0.106) \quad(0.105) \quad(0.147) \quad(0.139)$

\begin{tabular}{lcccc}
\hline Other controls & Yes & Yes & Yes & Yes \\
School fixed effects & No & No & Yes & Yes \\
\hline Observations & 2,753 & 2,759 & 2,753 & 2,759 \\
\hline
\end{tabular}

Note: Panel A reports the estimated regression coefficients of the classroom immigrant share at the beginning of the first school year on immigrants' standardized literacy (columns 1 and 3) and maths (columns 2 and 4) scores in the entrance exams. All regressions include controls for student age, gender, class size, share of females in the class and cohort dummies. Columns 1 and 2 exclude controls for school fixed effects, while columns 3 and 4 include them. Panel B presents the estimated coefficients of different quintiles of the classroom immigrant share (with the first quintile as the omitted variable). Robust standard errors (adjusted for clustering at the class level) are in parentheses, $* * * p<0.01, * * p<0.05, * p<0.1$

Table 4.4: Effect of immigrant share on native dropout probability

\begin{tabular}{|c|c|c|c|c|c|c|}
\hline & \multicolumn{6}{|c|}{ Dep. var.: dropout } \\
\hline & \multicolumn{2}{|c|}{ Full sample } & \multicolumn{2}{|c|}{ Low ability } & \multicolumn{2}{|c|}{ High ability } \\
\hline & $(1)$ & $(2)$ & (3) & (4) & $(5)$ & $(6)$ \\
\hline Immigrant share & $\begin{array}{c}0.125^{* * *} \\
(0.043)\end{array}$ & $\begin{array}{l}-0.081 \\
(0.051)\end{array}$ & $\begin{array}{l}0.084 * \\
(0.048)\end{array}$ & $\begin{array}{l}-0.082 \\
(0.067)\end{array}$ & $\begin{array}{c}0.162 * * * \\
(0.058)\end{array}$ & $\begin{array}{r}-0.046 \\
(0.071)\end{array}$ \\
\hline School fixed effects & No & Yes & No & Yes & $\mathrm{No}$ & Yes \\
\hline Other controls & Yes & Yes & Yes & Yes & Yes & Yes \\
\hline Observations & 20,840 & 20,840 & 10,391 & 10,391 & 10,449 & 10,449 \\
\hline \multicolumn{7}{|c|}{$\begin{array}{l}\text { Note: The table reports the estimated coefficients of the classroom immigrant share at the beginning of the first sch } \\
\text { year on the probability of native dropout. Other controls include the initial test score, age, gender, class size, share } \\
\text { females in the class and cohort dummies, as well as school fixed effects in columns } 2,4 \text {, and } 6 \text {. Columns } 1 \text { and } 2 \text { re } \\
\text { the estimates for the full sample, while columns } 3-4 \text { and } 5-6 \text { report them for low and high ability natives, respectiv } \\
\text { Ability is measured as the mean of the math and literacy test scores at entrance, with high versus low ability definec } \\
\text { scores above versus below the median. Robust standard errors (adjusted for clustering at the class level) are } \\
\text { parentheses, *** } p<0.01, * * p<0.05, * p<0.1\end{array}$} \\
\hline
\end{tabular}


Table 5.1: Effect of immigrant share on literacy and maths scores, overall and by ability

\begin{tabular}{|c|c|c|c|c|c|c|}
\hline & \multicolumn{3}{|c|}{ Literacy } & \multicolumn{3}{|c|}{ Maths } \\
\hline & $\begin{array}{c}\text { Full sample } \\
\text { (1) }\end{array}$ & $\begin{array}{c}\text { Low ability } \\
\text { (2) }\end{array}$ & $\begin{array}{c}\text { High ability } \\
\text { (3) }\end{array}$ & $\begin{array}{c}\text { Full sample } \\
\text { (4) }\end{array}$ & $\begin{array}{c}\text { Low ability } \\
(5)\end{array}$ & $\begin{array}{c}\text { High ability } \\
\text { (6) }\end{array}$ \\
\hline \multirow[t]{2}{*}{ IMMSHARE } & 0.126 & 0.010 & 0.206 & $-0.505^{* *}$ & $-0.809 * * *$ & -0.386 \\
\hline & $(0.171)$ & $(0.227)$ & $(0.214)$ & $(0.209)$ & $(0.241)$ & $(0.265)$ \\
\hline \multirow[t]{2}{*}{ Entrance test } & $0.371 * * *$ & $0.289 * * *$ & $0.366 * * *$ & $0.210 * * *$ & $0.110 * * *$ & $0.218 * * *$ \\
\hline & $(0.010)$ & $(0.018)$ & $(0.019)$ & $(0.012)$ & $(0.018)$ & $(0.018)$ \\
\hline \multirow[t]{2}{*}{ Female } & $-0.058 * *$ & $-0.120 * * *$ & 0.029 & $-0.083 * * *$ & $-0.103 * * *$ & -0.054 \\
\hline & $(0.027)$ & $(0.040)$ & $(0.037)$ & $(0.026)$ & $(0.037)$ & $(0.035)$ \\
\hline \multirow[t]{2}{*}{ Age } & $0.072 * * *$ & $0.094 * * *$ & $0.049 * * *$ & $0.040 * * *$ & 0.020 & $0.043 * * *$ \\
\hline & $(0.011)$ & $(0.017)$ & $(0.014)$ & $(0.010)$ & $(0.015)$ & $(0.014)$ \\
\hline \multirow[t]{2}{*}{ Class size } & 0.005 & 0.005 & $0.009 *$ & -0.003 & 0.003 & -0.006 \\
\hline & $(0.004)$ & $(0.006)$ & $(0.005)$ & $(0.006)$ & $(0.007)$ & $(0.008)$ \\
\hline \multirow[t]{2}{*}{ Share of females } & -0.104 & -0.055 & -0.224 & 0.173 & 0.185 & 0.200 \\
\hline & $(0.154)$ & $(0.228)$ & $(0.177)$ & $(0.210)$ & $(0.268)$ & $(0.230)$ \\
\hline \multirow[t]{2}{*}{ Cohort 2} & -0.034 & $-0.091 * * *$ & 0.018 & 0.059 & 0.028 & $0.090 * *$ \\
\hline & $(0.025)$ & $(0.035)$ & $(0.030)$ & $(0.037)$ & $(0.043)$ & $(0.045)$ \\
\hline School FE & Yes & Yes & Yes & Yes & Yes & Yes \\
\hline Observations & 11,835 & 5,768 & 6,067 & 11,817 & 5,768 & 6,049 \\
\hline
\end{tabular}

Note: Entries in the Table are the estimated coefficients of the classroom immigrant share and other control variables (standardized entrance test scores, female, age, class size, share of females in the class, and cohort 2 dummy) on standardized native literacy (columns 1-3) and maths (columns 4-6) scores. Columns 2-3 and 5-6 report separate estimates for the low and high ability natives, respectively. Ability is measured as the mean of the math and literacy test scores at entrance, with high versus low ability defined as scores above versus below the median. Robust standard errors (adjusted for clustering at the class level) in parentheses, ${ }^{* * *} p<0.01, * * p<0.05, * p<0.1$ 
Table 5.2: Non-linear effect of immigrant share

\begin{tabular}{|c|c|c|c|c|c|c|}
\hline \multirow[b]{2}{*}{ IMMSHARE quintile } & \multicolumn{3}{|c|}{ Literacy } & \multicolumn{3}{|c|}{ Maths } \\
\hline & $\begin{array}{c}\text { Full sample } \\
\text { (1) }\end{array}$ & $\begin{array}{c}\text { Low ability } \\
\text { (2) }\end{array}$ & $\begin{array}{c}\text { High ability } \\
\text { (3) }\end{array}$ & $\begin{array}{c}\text { Full sample } \\
\text { (4) }\end{array}$ & $\begin{array}{c}\text { Low ability } \\
(5)\end{array}$ & $\begin{array}{c}\text { High ability } \\
\text { (6) }\end{array}$ \\
\hline \multirow[t]{2}{*}{$2^{\text {nd }}$} & -0.016 & -0.073 & 0.022 & -0.027 & -0.111 & 0.011 \\
\hline & $(0.046)$ & $(0.061)$ & $(0.055)$ & $(0.062)$ & $(0.070)$ & $(0.070)$ \\
\hline \multirow[t]{2}{*}{$3^{\text {rd }}$} & 0.007 & -0.000 & 0.022 & 0.005 & -0.068 & 0.026 \\
\hline & $(0.047)$ & $(0.066)$ & $(0.053)$ & $(0.063)$ & $(0.073)$ & $(0.071)$ \\
\hline \multirow[t]{2}{*}{$4^{\text {th }}$} & -0.043 & -0.071 & -0.011 & -0.075 & $-0.212 * *$ & -0.002 \\
\hline & $(0.057)$ & $(0.076)$ & $(0.071)$ & $(0.077)$ & $(0.085)$ & $(0.098)$ \\
\hline \multirow[t]{2}{*}{$5^{\text {th }}$} & 0.077 & 0.008 & 0.119 & $-0.248 * * *$ & $-0.335 * * *$ & $-0.222 * *$ \\
\hline & $(0.063)$ & $(0.085)$ & $(0.078)$ & $(0.086)$ & $(0.096)$ & $(0.109)$ \\
\hline Other controls & Yes & Yes & Yes & Yes & Yes & Yes \\
\hline School fixed effect & Yes & Yes & Yes & Yes & Yes & Yes \\
\hline Observations & 11,835 & 5,768 & 6,067 & 11,817 & 5,768 & 6,049 \\
\hline
\end{tabular}

Note: The table reports the estimated coefficients of different quintiles of classroom immigrant share (with the $1^{\text {st }}$ quintile as the omitted category) on native standardized literacy (columns 1-3) and maths (columns 4-6) scores. Other controls include standardized entrance test scores, female, age, class size, share of females in the class, and a cohort 2 dummy. Columns 2-3 and 5-6 report separate estimates for low and high ability natives, respectively. Ability is measured as the mean of the math and literacy test scores at entrance, with high versus low ability defined as scores above versus below the median. Robust standard errors (adjusted for clustering at the class level) are in parentheses, $* * * p<0.01, * * p<0.05, * p<0.1$

Table 5.3: Heterogeneity by cultural diversity or linguistic distance

\begin{tabular}{lcccc}
\hline \hline & \multicolumn{3}{c}{ Literacy } & \multicolumn{2}{c}{ Maths } \\
\cline { 2 - 5 } & $(1)$ & $(2)$ & $(3)$ & $(4)$ \\
& & By cultural diversity (DIV) & High \\
\cline { 2 - 5 } & Low & High & Low & -0.091 \\
\hline IMMSHARE & 0.167 & 0.310 & -0.479 & $(0.371)$ \\
\hline Other controls & $(0.326)$ & $(0.274)$ & $(0.344)$ & yes \\
School fixed effects & yes & yes & yes & yes \\
Observations & yes & yes & yes & 5,484 \\
\hline
\end{tabular}

\begin{tabular}{lcccc} 
& \multicolumn{4}{c}{ By linguistic distance (LDI) } \\
\cline { 2 - 5 } & Low & High & Low & High \\
\hline IMMSHARE & 0.438 & -0.125 & -0.086 & $-0.897 * *$ \\
& $(0.312)$ & $(0.302)$ & $(0.353)$ & $(0.362)$ \\
\hline Other controls & Yes & Yes & Yes & Yes \\
School fixed effects & Yes & Yes & Yes & Yes \\
Observations & 5,365 & 5,148 & 5,354 & 5,140 \\
\hline \hline
\end{tabular}

Note: The table reports the estimated coefficients of classroom immigrant share on natives' standardized literacy (columns 1-3) and maths (columns 4-6) scores. Other controls include standardized entrance test scores, female, age, class size, share of females in the class, and a cohort 2 dummy. All regressions include school fixed effects. The cultural diversity index (DIV) is equal to 1 minus the Hirschman-Herfindahl index, with groups defined based on immigrant country of birth. The language dissimilarity index (LDI) is each class's mean on the Levenshtein index. Robust standard errors (adjusted for clustering at the class level) are in parentheses, *** $p<0.01, * * \mathrm{p}<0.05, * \mathrm{p}<0.1$ 
Table 5.4: Linear and nonlinear effects, by linguistic distance and ability

\begin{tabular}{|c|c|c|c|c|}
\hline & \multicolumn{2}{|c|}{ Low LDI } & \multicolumn{2}{|c|}{ High LDI } \\
\hline & $\begin{array}{c}\text { Low ability } \\
(1)\end{array}$ & $\begin{array}{c}\text { High ability } \\
\text { (2) }\end{array}$ & $\begin{array}{c}\text { Low ability } \\
(3)\end{array}$ & $\begin{array}{c}\text { High ability } \\
\text { (4) }\end{array}$ \\
\hline & \multicolumn{4}{|c|}{ Panel A: linear effects } \\
\hline IMMSHARE & $\begin{array}{l}-0.209 \\
(0.386)\end{array}$ & $\begin{array}{l}-0.367 \\
(0.405)\end{array}$ & $\begin{array}{c}-1.292 * * * \\
(0.455)\end{array}$ & $\begin{array}{l}-0.456 \\
(0.452)\end{array}$ \\
\hline Other controls & Yes & Yes & Yes & Yes \\
\hline School fixed effects & Yes & Yes & Yes & Yes \\
\hline Observations & 2,685 & 2,669 & 2,501 & 2,639 \\
\hline IMMSHARE quintile & \multicolumn{4}{|c|}{ Panel B: non-linear effects } \\
\hline $2^{\text {nd }}$ & $\begin{array}{c}-0.306 * * \\
(0.120)\end{array}$ & $\begin{array}{l}-0.006 \\
(0.116)\end{array}$ & $\begin{array}{l}-0.108 \\
(0.195)\end{array}$ & $\begin{array}{l}-0.116 \\
(0.141)\end{array}$ \\
\hline $3^{\text {rd }}$ & $\begin{array}{l}-0.023 \\
(0.122)\end{array}$ & $\begin{array}{l}-0.057 \\
(0.103)\end{array}$ & $\begin{array}{l}-0.084 \\
(0.176)\end{array}$ & $\begin{array}{l}-0.044 \\
(0.136)\end{array}$ \\
\hline $4^{\text {th }}$ & $\begin{array}{l}-0.162 \\
(0.122)\end{array}$ & $\begin{array}{l}-0.019 \\
(0.095)\end{array}$ & $\begin{array}{l}-0.215 \\
(0.186)\end{array}$ & $\begin{array}{l}-0.159 \\
(0.140)\end{array}$ \\
\hline $5^{\text {th }}$ & $\begin{array}{l}-0.082 \\
(0.138)\end{array}$ & $\begin{array}{l}-0.118 \\
(0.181)\end{array}$ & $\begin{array}{c}-0.500 * * \\
(0.199)\end{array}$ & $\begin{array}{l}-0.330 * \\
(0.180)\end{array}$ \\
\hline Other controls & Yes & Yes & Yes & Yes \\
\hline School fixed effects & Yes & Yes & Yes & Yes \\
\hline Observations & 2,685 & 2,669 & 2,501 & 2,639 \\
\hline
\end{tabular}

Note: Panel A gives the estimated coefficients of classroom immigrant share on natives' standardized maths scores. Other controls include standardized entrance test scores, female, age, class size, share of females in the class, and cohort 2 dummy. All regressions include school fixed effects. The language dissimilarity index (LDI) is each class's mean on the Levenshtein index. Ability is measured as the mean of the math and literacy test scores at entrance, with high versus low ability defined as scores above versus below the median. Panel B presents the estimated coefficients of different quintiles of the classroom immigrant share (with the first quintile as the omitted variable). Robust standard errors (adjusted for clustering at the class level) are in parentheses, $* * * p<0.01, * * p<0.05, * p<0.1$ 
Table 5.5: Association between the standardized Levenshtein linguistic distance index and immigrants' initial test scores in literacy and maths

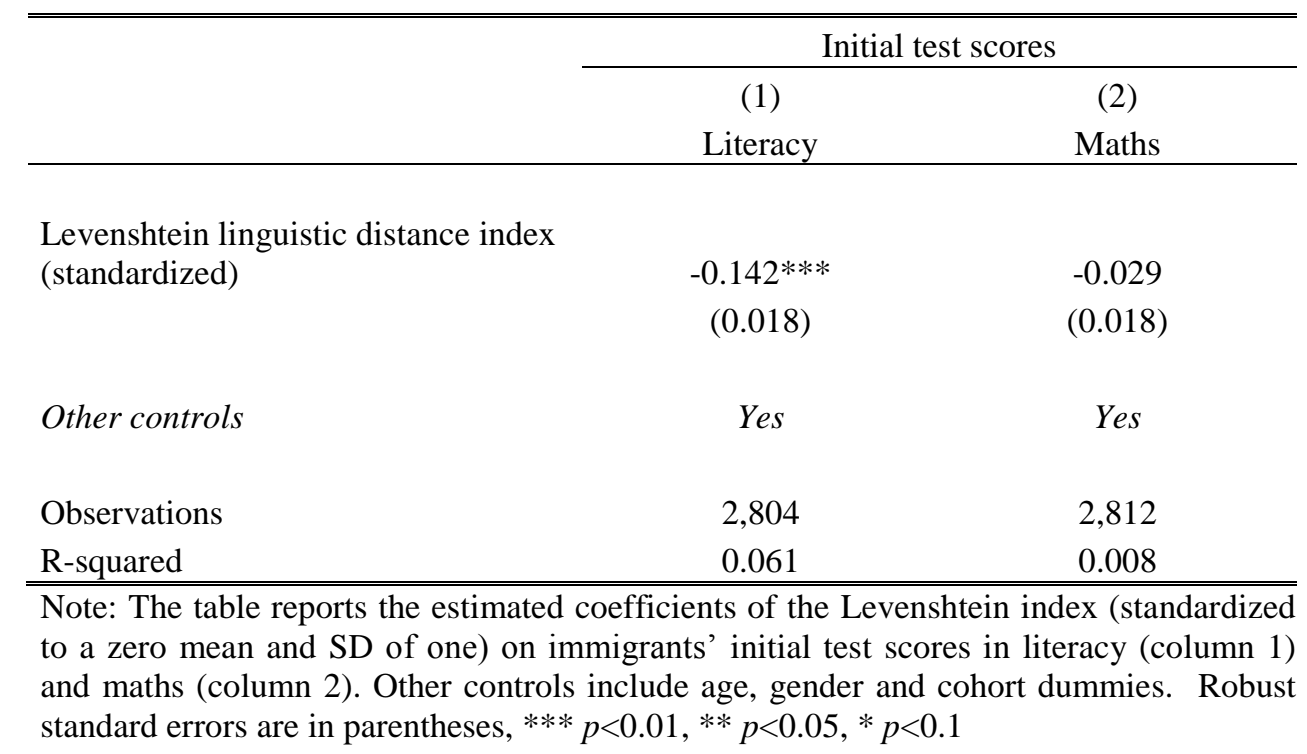

Table 6.1: Effect of immigrant share on class size and on test scores

\begin{tabular}{|c|c|c|c|c|c|c|c|}
\hline & \multirow{2}{*}{$\begin{array}{c}\text { Class size } \\
(1) \\
\end{array}$} & \multicolumn{3}{|c|}{ Literacy } & \multicolumn{3}{|c|}{ Maths } \\
\hline & & $\begin{array}{c}\text { Full sample } \\
\text { (2) }\end{array}$ & $\begin{array}{c}\text { Low ability } \\
\text { (3) }\end{array}$ & $\begin{array}{c}\text { High ability } \\
\text { (4) }\end{array}$ & $\begin{array}{c}\text { Full sample } \\
\text { (5) }\end{array}$ & $\begin{array}{c}\text { Low ability } \\
(6)\end{array}$ & $\begin{array}{c}\text { High ability } \\
\text { (7) }\end{array}$ \\
\hline Immigrant share & $\begin{array}{l}-1.668 \\
(1.212)\end{array}$ & $\begin{array}{c}0.120 \\
(0.171)\end{array}$ & $\begin{array}{c}0.004 \\
(0.226)\end{array}$ & $\begin{array}{c}0.189 \\
(0.215)\end{array}$ & $\begin{array}{c}-0.501 * * \\
(0.210)\end{array}$ & $\begin{array}{c}-0.811^{* * * *} \\
(0.240)\end{array}$ & $\begin{array}{l}-0.376 \\
(0.269)\end{array}$ \\
\hline Entrance test & & $\begin{array}{c}0.371 * * * \\
(0.010)\end{array}$ & $\begin{array}{c}0.289 * * * \\
(0.018)\end{array}$ & $\begin{array}{c}0.366^{* * * *} \\
(0.019)\end{array}$ & $\begin{array}{c}0.210 * * * \\
(0.012)\end{array}$ & $\begin{array}{c}0.110^{* * * *} \\
(0.018)\end{array}$ & $\begin{array}{c}0.218 * * * \\
(0.019)\end{array}$ \\
\hline Female & & $\begin{array}{c}-0.058 * * \\
(0.027)\end{array}$ & $\begin{array}{c}-0.120 * * * \\
(0.040)\end{array}$ & $\begin{array}{c}0.030 \\
(0.037)\end{array}$ & $\begin{array}{c}-0.083 * * * \\
(0.026)\end{array}$ & $\begin{array}{c}-0.103 * * * \\
(0.037)\end{array}$ & $\begin{array}{l}-0.055 \\
(0.035)\end{array}$ \\
\hline Age & & $\begin{array}{c}0.072 * * * \\
(0.011)\end{array}$ & $\begin{array}{c}0.093 * * * \\
(0.017)\end{array}$ & $\begin{array}{c}0.048 * * * \\
(0.014)\end{array}$ & $\begin{array}{c}0.040 * * * \\
(0.010)\end{array}$ & $\begin{array}{c}0.020 \\
(0.015)\end{array}$ & $\begin{array}{c}0.044 * * * \\
(0.014)\end{array}$ \\
\hline Share of females & & $\begin{array}{l}-0.103 \\
(0.155)\end{array}$ & $\begin{array}{l}-0.060 \\
(0.229)\end{array}$ & $\begin{array}{l}-0.217 \\
(0.177)\end{array}$ & $\begin{array}{c}0.173 \\
(0.210)\end{array}$ & $\begin{array}{c}0.183 \\
(0.269)\end{array}$ & $\begin{array}{c}0.195 \\
(0.231)\end{array}$ \\
\hline Cohort 2 & $\begin{array}{c}1.177 * * * \\
(0.211)\end{array}$ & $\begin{array}{l}-0.029 \\
(0.025)\end{array}$ & $\begin{array}{c}-0.085 * * \\
(0.035)\end{array}$ & $\begin{array}{c}0.025 \\
(0.030)\end{array}$ & $\begin{array}{c}0.056 \\
(0.035)\end{array}$ & $\begin{array}{c}0.030 \\
(0.043)\end{array}$ & $\begin{array}{c}0.085 * * \\
(0.043)\end{array}$ \\
\hline School FE & Yes & Yes & Yes & Yes & Yes & Yes & Yes \\
\hline Class size & - & No & No & No & No & $\mathrm{No}$ & No \\
\hline Observations & 1,244 & 11,835 & 5,768 & 6,067 & 11,817 & 5,768 & 6,049 \\
\hline
\end{tabular}

Note: Entries in the Table are the estimated coefficients of the classroom immigrant share on class size (col 1) and on standardized native literacy (columns 2-4) and maths (columns 5-7) scores. Estimation in column 1 is performed on class-level data. Columns 3-4 and 6-7 report separate estimates for the low and high ability natives, respectively. Ability is measured as the mean of the math and literacy test scores at entrance, with high versus low ability defined as scores above versus below the median. Robust standard errors (adjusted for clustering at the class level) in parentheses, *** $p<0.01, * * p<0.05, * p<0.1$ 
Table 6.2: Effect of immigrant share on immigrants' scores, overall and by ability

\begin{tabular}{|c|c|c|c|c|c|c|}
\hline & \multicolumn{3}{|c|}{ Literacy } & \multicolumn{3}{|c|}{ Maths } \\
\hline & $\begin{array}{c}\text { Full sample } \\
\text { (1) }\end{array}$ & $\begin{array}{c}\text { Low ability } \\
\text { (2) }\end{array}$ & $\begin{array}{c}\text { High ability } \\
\text { (3) }\end{array}$ & $\begin{array}{c}\text { Full sample } \\
\text { (4) }\end{array}$ & $\begin{array}{c}\text { Low ability } \\
(5)\end{array}$ & $\begin{array}{c}\text { High ability } \\
\text { (6) }\end{array}$ \\
\hline \multirow{2}{*}{ IMMSHARE } & 0.016 & 0.117 & -0.157 & -0.002 & 0.189 & -0.348 \\
\hline & $(0.280)$ & $(0.433)$ & $(0.383)$ & $(0.319)$ & $(0.403)$ & $(0.390)$ \\
\hline \multirow[t]{2}{*}{ Entrance test } & $0.324 * * *$ & $0.236 * * *$ & $0.305 * * *$ & $0.186 * * *$ & $0.120 * *$ & $0.209 * * *$ \\
\hline & $(0.024)$ & $(0.059)$ & $(0.044)$ & $(0.020)$ & $(0.050)$ & $(0.037)$ \\
\hline \multirow[t]{2}{*}{ Female } & -0.119 & $-0.362 * *$ & 0.028 & -0.104 & $-0.197 *$ & -0.069 \\
\hline & $(0.081)$ & $(0.159)$ & $(0.128)$ & $(0.067)$ & $(0.115)$ & $(0.107)$ \\
\hline \multirow[t]{2}{*}{ Age } & -0.025 & 0.026 & $-0.075^{* *}$ & 0.009 & 0.025 & 0.000 \\
\hline & $(0.021)$ & $(0.035)$ & $(0.034)$ & $(0.017)$ & $(0.027)$ & $(0.026)$ \\
\hline \multirow[t]{2}{*}{ Class size } & -0.005 & 0.001 & -0.011 & 0.002 & -0.013 & 0.004 \\
\hline & $(0.010)$ & $(0.017)$ & $(0.015)$ & $(0.010)$ & $(0.016)$ & $(0.013)$ \\
\hline \multirow[t]{2}{*}{ Share of females } & $-0.853 * *$ & -0.690 & -0.525 & -0.410 & -0.004 & -0.638 \\
\hline & $(0.433)$ & $(0.739)$ & $(0.579)$ & $(0.338)$ & $(0.558)$ & $(0.433)$ \\
\hline \multirow[t]{2}{*}{ Cohort 2} & 0.085 & 0.017 & $0.151 * *$ & 0.084 & 0.022 & 0.111 \\
\hline & $(0.055)$ & $(0.098)$ & $(0.075)$ & $(0.053)$ & $(0.081)$ & $(0.074)$ \\
\hline School FE & Yes & Yes & Yes & Yes & Yes & Yes \\
\hline Observations & 2,599 & 1,260 & 1,339 & 2,604 & 1,260 & 1,344 \\
\hline
\end{tabular}

Note: Entries in the Table are the estimated coefficients of the classroom immigrant share and other control variables (standardized entrance test scores, female, age, class size, share of females in the class, and cohort 2 dummy) on standardized immigrant literacy (columns 1-3) and maths (columns 4-6) scores. Columns 2-3 and 5-6 report separate estimates for the low and high ability immigrants, respectively. Ability is measured as the mean of the math and literacy test scores at entrance, with high versus low ability defined as scores above versus below the median. Robust standard errors (adjusted for clustering at the class level) in parentheses, $* * * p<0.01, * * p<0.05, *$ $p<0.1$ 
Table 6.3: Effects of immigrant share on immigrants' scores, by cultural diversity or linguistic distance

\begin{tabular}{|c|c|c|c|c|}
\hline & \multicolumn{2}{|c|}{ Literacy } & \multicolumn{2}{|c|}{ Maths } \\
\hline & (1) & (2) & (3) & (4) \\
\hline & \multicolumn{4}{|c|}{ By cultural diversity (DIV) } \\
\hline & Low & High & Low & High \\
\hline IMMSHARE & -0.943 & 0.427 & -0.412 & 0.322 \\
\hline & $(0.698)$ & $(0.449)$ & $(0.783)$ & $(0.398)$ \\
\hline Other controls & yes & yes & yes & yes \\
\hline School fixed effects & yes & yes & yes & yes \\
\hline \multirow[t]{3}{*}{ Observations } & 1,149 & 1,450 & 1,155 & 1,449 \\
\hline & \multicolumn{4}{|c|}{ By linguistic distance (LDI) } \\
\hline & Low & High & Low & High \\
\hline \multirow[t]{2}{*}{ IMMSHARE } & -0.422 & 0.051 & $1.055^{* *} *$ & 0.171 \\
\hline & $(0.847)$ & $(0.330)$ & $(0.522)$ & $(0.418)$ \\
\hline Other controls & Yes & Yes & Yes & Yes \\
\hline School fixed effects & Yes & Yes & Yes & Yes \\
\hline Observations & 955 & 1,630 & 956 & 1,634 \\
\hline \multicolumn{5}{|c|}{$\begin{array}{l}\text { Note: The table reports the estimated coefficients of classroom immigrant share on immigrants' standardized } \\
\text { literacy (columns } 1-3 \text { ) and maths (columns } 4-6 \text { ) scores. Other controls include standardized entrance test scores, } \\
\text { female, age, class size, share of females in the class, and a cohort } 2 \text { dummy. All regressions include school fixed } \\
\text { effects. The cultural diversity index (DIV) is equal to } 1 \text { minus the Hirschman-Herfindahl index, with groups } \\
\text { defined based on immigrant country of birth. The language dissimilarity index (LDI) is each class's mean on the } \\
\text { Levenshtein index. Robust standard errors (adjusted for clustering at the class level) are in parentheses, *** } \\
p<0.01, * * p<0.05, * p<0.1\end{array}$} \\
\hline
\end{tabular}

Table 6.4: Effects of immigrant share on immigrants' maths scores, by linguistic distance and ability

\begin{tabular}{lcccc}
\hline \hline & \multicolumn{2}{c}{ Low LDI } & \multicolumn{2}{c}{ High LDI } \\
\cline { 2 - 5 } & Low ability & High ability & Low ability & High ability \\
& $(1)$ & $(2)$ & $(3)$ & 0.081 \\
\hline \hline IMMSHARE & 0.532 & $1.625^{* *}$ & -0.061 & $(0.513)$ \\
& $(0.852)$ & $(0.692)$ & $(0.541)$ & Yes \\
\hline Other controls & Yes & Yes & Yes & Yes \\
School fixed effects & Yes & Yes & Yes & 829 \\
Observations & 448 & 508 & 805 & ises \\
\hline \hline
\end{tabular}

Note: The Table gives the estimated coefficients of classroom immigrant share on immigrants' standardized maths scores. Other controls include standardized entrance test scores, female, age, class size, share of females in the class, and cohort 2 dummy. All regressions include school fixed effects. The language dissimilarity index (LDI) is each class's mean on the Levenshtein index. Ability is measured as the mean of the math and literacy test scores at entrance, with high versus low ability defined as scores above versus below the median. Robust standard errors (adjusted for clustering at the class level) are in parentheses, $* * * p<0.01, * * p<0.05, * p<0.1$ 
Table 6.5: Effect of immigrant share in the class on natives' maths scores, by ability and by average employment rate (Panel $A$ ) and by average duration of stay in Italy (Panel B) of the immigrant group.

(4)

(5)

(6)

Panel A: By average employment rate

\begin{tabular}{lcccccc} 
& \multicolumn{3}{c}{ Low employment rate } & \multicolumn{3}{c}{ High employment rate } \\
& Full sample & Low ability & High ability & Full sample & Low ability & High ability \\
\cline { 2 - 7 } IMMSHARE & $-0.961^{* * *}$ & $-1.338^{* * *}$ & -0.667 & 0.341 & 0.240 & 0.321 \\
& $(0.330)$ & $(0.389)$ & $(0.434)$ & $(0.432)$ & $(0.525)$ & $(0.512)$ \\
& & & & & & \\
Other controls & Yes & Yes & Yes & Yes & Yes & Yes \\
School fixed effects & Yes & Yes & Yes & Yes & Yes & Yes \\
Observations & 5,238 & 2,595 & 2,643 & 3,826 & 1,903 & 1,923 \\
& & & & & & \\
\hline
\end{tabular}

Panel B: By average duration of stay in Italy

\begin{tabular}{lcccccc} 
& \multicolumn{3}{c}{ Short stay } & & \multicolumn{3}{c}{ Long stay } \\
& Full sample & Low ability & High ability & Full sample & Low ability & High ability \\
\cline { 2 - 7 } IMMSHARE & -0.469 & $-0.981^{* *}$ & 0.008 & $-0.701^{*}$ & -0.733 & -0.769 \\
& $(0.336)$ & $(0.423)$ & $(0.430)$ & $(0.398)$ & $(0.495)$ & $(0.498)$ \\
& & & & & & \\
\hline Other controls & Yes & Yes & Yes & Yes & Yes & Yes \\
School fixed effects & Yes & Yes & Yes & Yes & Yes & Yes \\
Observations & 4,831 & 2,432 & 2,399 & 4,233 & 2,066 & 2,167
\end{tabular}

Note: The Table gives the estimated coefficients of classroom immigrant share on immigrants' standardized maths scores. Other controls include standardized entrance test scores, female, age, class size, share of females in the class, and cohort 2 dummy. All regressions include school fixed effects. In Panel A we distinguish between classes characterized by a low (columns 1-3) or high (columns 4-6) average employment rate in the communities of origin of immigrant students- In Panel A we distinguish between classes characterized by a low (columns 1-3) or high (columns 4-6) average stay in Italy among the communities of origin of immigrant students. Ability is measured as the mean of the math and literacy test scores at entrance. In all cases, high versus low is defined as above versus below the median of the respective measure. Robust standard errors (adjusted for clustering at the class level) are in parentheses, $* * * p<0.01, * * p<0.05, * p<0.1$ 
Dep. var: Maths test scores

$(1)$
(2)

By linguistic distance (LDI)

\begin{tabular}{|c|c|c|c|c|}
\hline & \multicolumn{4}{|c|}{ By linguistic distance (LDI) } \\
\hline & Low & High & Low & High \\
\hline \multirow[t]{2}{*}{ IMMSHARE } & 0.438 & $-0.856^{* *}$ & & \\
\hline & $(0.396)$ & $(0.363)$ & & \\
\hline \multirow[t]{2}{*}{ Average emp. rate of immigrant groups in the class } & 0.421 & -0.498 & & \\
\hline & $(0.660)$ & $(0.425)$ & & \\
\hline \multirow[t]{2}{*}{ IMMSHARE } & & & 0.381 & $-0.980 * * *$ \\
\hline & & & $(0.372)$ & $(0.367)$ \\
\hline \multirow[t]{2}{*}{ Average length of stay of immigrant groups in the class } & & & $0.033^{* * *}$ & -0.014 \\
\hline & & & $(0.012)$ & $(0.009)$ \\
\hline Other controls & Yes & Yes & Yes & Yes \\
\hline School fixed effects & Yes & Yes & Yes & Yes \\
\hline Observations & 3,811 & 5,140 & 3,811 & 5,140 \\
\hline
\end{tabular}

Note: The table reports the estimated coefficients of classroom immigrant share on natives' standardized maths by linguistic distance. Other controls include standardized entrance test scores, female, age, class size, share of females in the class, and a cohort 2 dummy. All regressions include school fixed effects. Columns 1 and 2 ( 3 and 4) additionally include the class-level average employment rate (years since migration in Italy) of the immigrant communities of origin of foreign students. The language dissimilarity index (LDI) is each class's mean on the Levenshtein index. Robust standard errors (adjusted for clustering at the class level) are in parentheses, $* * *$ $p<0.01, * * \mathrm{p}<0.05, * \mathrm{p}<0.1$ 